\title{
Honeybee health in Africa—a review
}

\author{
Christian W. W. Pirk, Ursula Strauss, Abdullahi A. Yusuf, Fabien DÉmares, \\ Hannelie HuMAN
}

\begin{abstract}
Social Insects Research Group, Department of Zoology and Entomology, University of Pretoria, Private Bag X20, Hatfield, 0028, Pretoria, South Africa
\end{abstract}

Received 30 April 2015 - Revised 9 October 2015 - Accepted 26 October 2015

\begin{abstract}
Honeybee (Apis mellifera L.) pathogens and parasites and the negative effects thereof on honeybee populations remain an issue of public concern and the subject of active research. Africa with its high genetic diversity of honeybee sub-species and large wild population is also exposed to various factors responsible for colony losses in other parts of the world. Apart from the current American foulbrood epidemic in the Western Cape of South Africa, no large-scale colony losses have been reported elsewhere on the continent. We discuss the presence of pathogens, parasites, pests and predators of African honeybees as well as the threats they face in relation to habitat changes arising from the impact of increased human populations. In addition, we discuss current efforts aimed at protecting and promoting the health of African honeybees.
\end{abstract}

honeybees / Africa / honeybee health / pathogens / parasites / pests / predators / habitat loss

\section{INTRODUCTION}

The crucial service and economic value of the majority of Apis and non-Apis pollinators have been reviewed and debated extensively (Aebi et al. 2012; Ollerton et al. 2012; Vanbergen et al. 2013). Honeybees (Apis mellifera L.), both wild and managed, are responsible for the pollination of numerous crops and plants, contributing not only to food security but also the economy (Klein et al. 2007; Allsopp et al. 2008; vanEngelsdorp and Meixner 2010). The decline in honeybee numbers is alarming given their important role in ecosystem services (Neumann and Carreck 2010; Vanbergen et al. 2013). Concern about the decline in colony numbers is warranted in light of the growing demand for crop pollination and added pressure for a sufficient supply of

Corresponding author: H. Human, hhuman@zoology.up.ac.za

Manuscript editor: Marina Meixner honeybee colonies (Aizen and Harder 2009; Neumann and Carreck 2010; Goulson et al. 2015).

In recent years, there have been increased research efforts to understand and provide solutions for the large colony losses experienced in many parts of the world (Moritz et al. 2010a; Neumann and Carreck 2010; Smith et al. 2013). A combination of factors have been identified as possible drivers of these colony losses (Neumann and Carreck 2010; Potts et al. 2010; vanEngelsdorp and Meixner 2010; Smith et al. 2013; Pirk et al. 2014; McMenamin and Genersch 2015). One key driver is the international trade in honeybees and bee products, which serves as an active means for the introduction of non-native species and the consequential spread of pathogens, parasites and pests (e.g. recent introduction of small hive beetles in Italy) (Mutinelli 2011; Mutinelli et al. 2014). As experienced in other parts of the world, honeybee populations in Africa have also been affected by the introduction of novel pathogens, parasites and pests (Varroa destructor, American foulbrood, Nosema ceranae) as well as habitat loss (Hussein 2001a, b; Dietemann et al. 2009). 
Despite the different threats, Africa seems fortunate as it contains a large endemic wild population of honeybees (Dietemann et al. 2009), which shows a significantly higher genetic diversity than other honeybee populations (Wallberg et al. 2014). In addition, African apiculture has room for growth since only a small proportion of honeybee colonies are commercially managed, with beekeeping in many countries still based on traditional practices (Johannsmeier 2001; Dietemann et al. 2009). Therefore, Africa's large wild population may still be able to adapt to new threats, like diseases, without human interference.

Here, we will focus on the diversity of African honeybees as well as the various problems they face including pathogens, parasites, pests, predators, pesticides and habitat transformation. Efforts currently in place aimed at protecting African honeybee health will also be highlighted.

\section{HONEYBEES OF AFRICA}

Globally, many A. mellifera L. sub-species (up to 30) have been described in the literature (Ruttner 1988, 1992; Hepburn and Radloff 1998; Bouga et al. 2011; da Silva et al. 2015). Sub-species are mainly classified based on various morphological characteristics, and more recently, molecular techniques have also been applied (Ruttner 1988; Meixner et al. 2013). Africa and Madagascar are home to 11 honeybee sub-species, namely Apis mellifera intermissa, Apis mellifera sahariensis, Apis mellifera lamarckii, Apis mellifera jemenitica (sometimes called Apis mellifera nubi, Apis mellifera sudanensis or Apis mellifera bandasii), Apis mellifera monticola, Apis mellifera litorea, Apis mellifera adansonii, Apis mellifera scutellata, Apis mellifera capensis and Apis mellifera unicolor (Hepburn and Radloff 1998; Engel 1999; Franck et al. 2001; Al-Ghamdi et al. 2013). Recently, Meixner et al. (2011) proposed Apis mellifera simensis as a new sub-species in Ethiopia based on morphometrical features. A. mellifera intermissa, A. mellifera sahariensis and A. mellifera lamarckii occur in the northern parts of Africa, while the remaining eight sub-species occupy the rest of the continent, with the exception of A. mellifera unicolor which is found in Madagascar (Ruttner 1988; Hepburn and Radloff 1998; Engel 1999). The conservation of African honeybees is fundamental to maintain the large wild population and high genetic diversity. They may be less susceptible to various pathogens, parasites, pests and predators, as a result of natural selection occurring due to a lack of human intervention.

\section{PATHOGENS, PARASITES, PESTS AND PREDATORS OF AFRICAN HONEYBEES}

Most of the pathogens and parasites affecting global honeybee colony health are present throughout Africa (Bradbear 1988; Matheson 1993, 1995; Allen and Ball 1996; Hepburn and Radloff 1998; Hussein 2001a, b; Swart et al. 2001; Ellis and Munn 2005; Mumoki et al. 2014). We discuss, summarise (Table I) and illustrate (Figures 1, 2 and 3) most of the pathogens, parasites, pests and predators known to be present on the mainland Africa and highlight potential consequences for these honeybee populations.

\subsection{Bacteria}

\subsubsection{American foulbrood (Paenibacillus larvae)}

American foulbrood (AFB) is widely distributed in many African countries, except the central region (Ellis and Munn 2005; Human et al. 2011; Mumoki et al. 2014). AFB, caused by Paenibacillus larvae, affects the larval stage (mostly after capping) and can be transmitted by adult honeybees within and between colonies (Lindström et al. 2008). AFB is a notifiable disease of the OIE (Office International des Epizooties/World Organisation for Animal Health). It has been suggested that African honeybees are less susceptible and more capable of dealing with most parasites and pathogens (Fries and Raina 2003), either by expressing stronger hygienic 


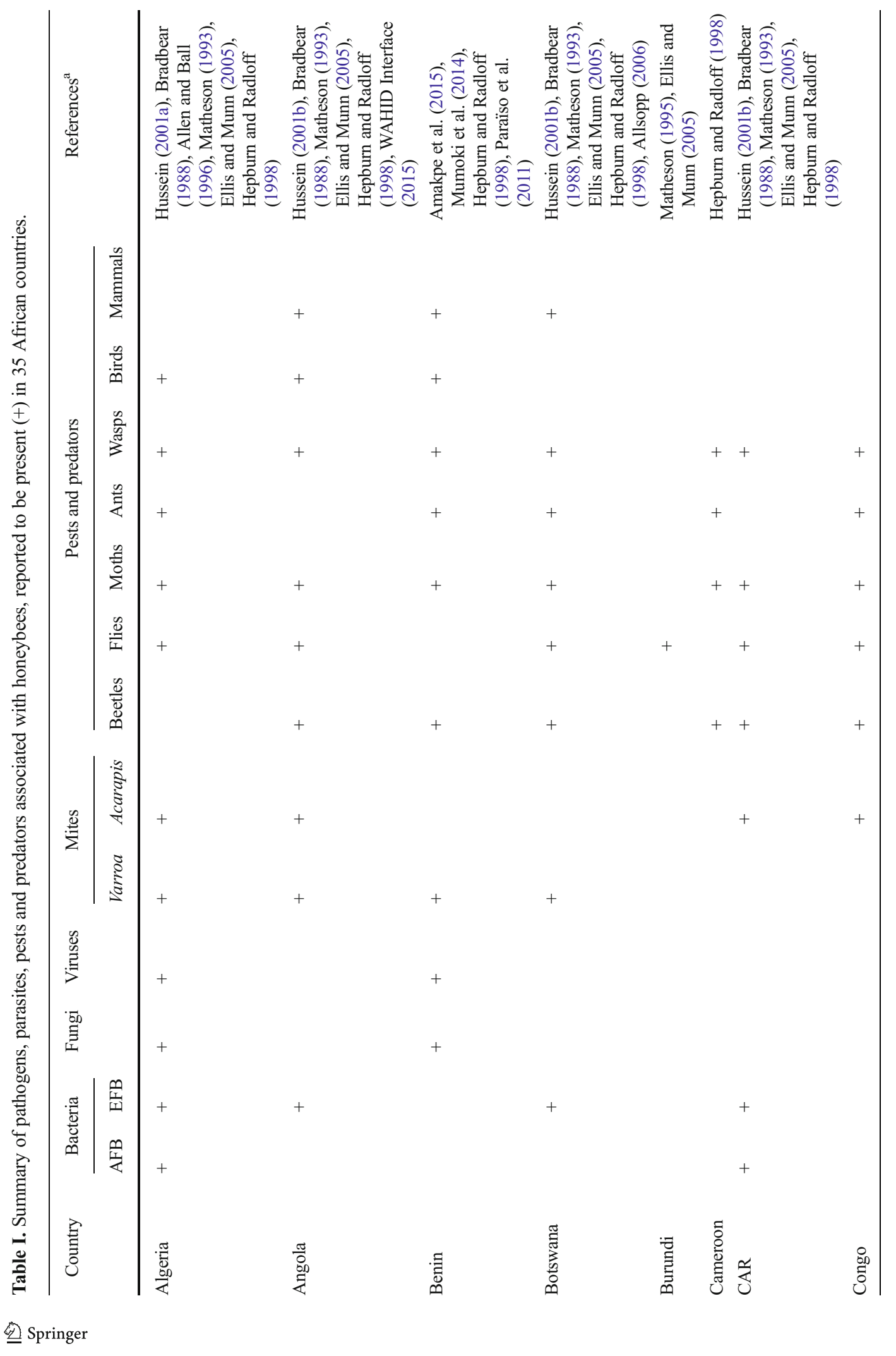




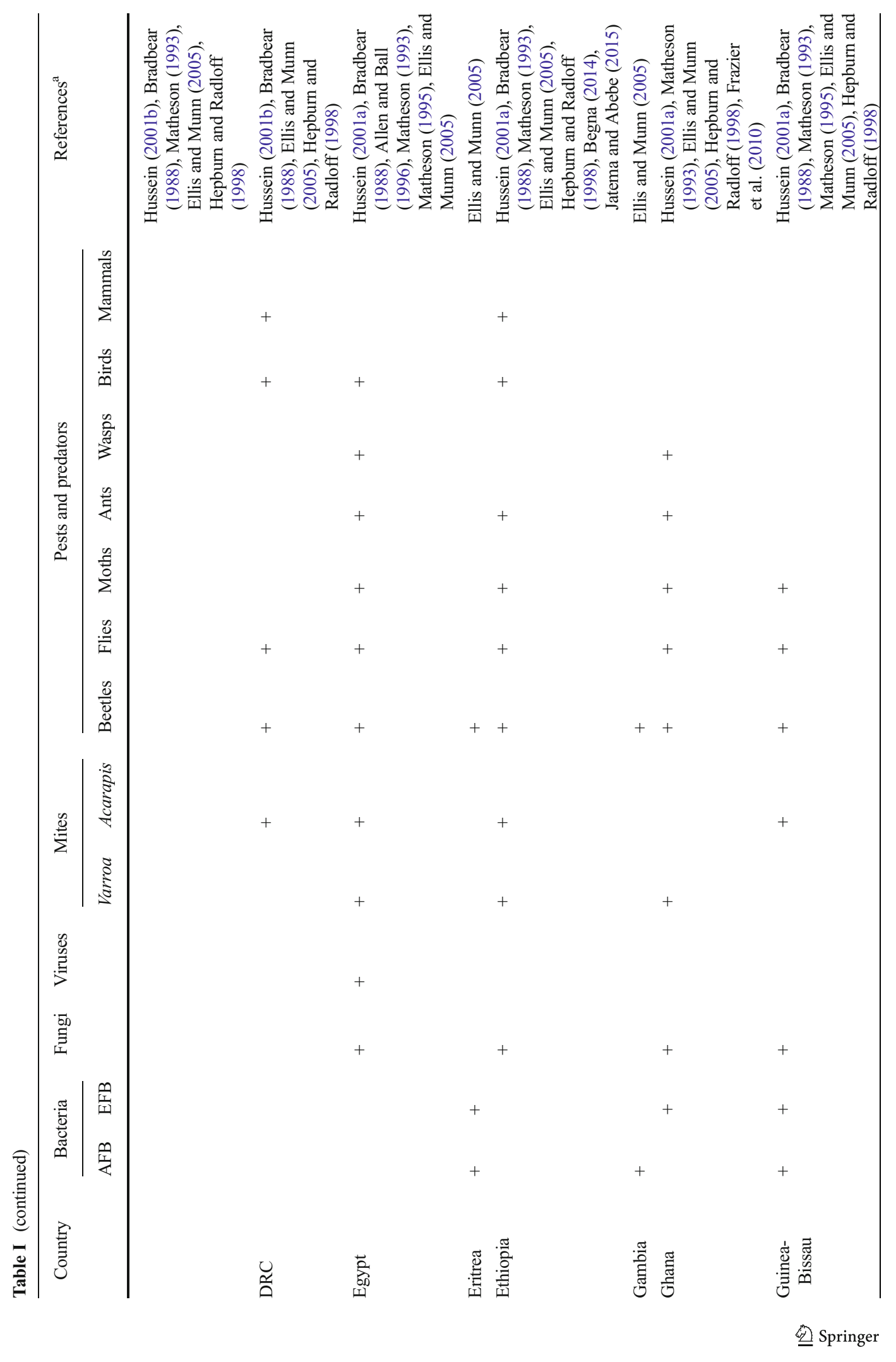




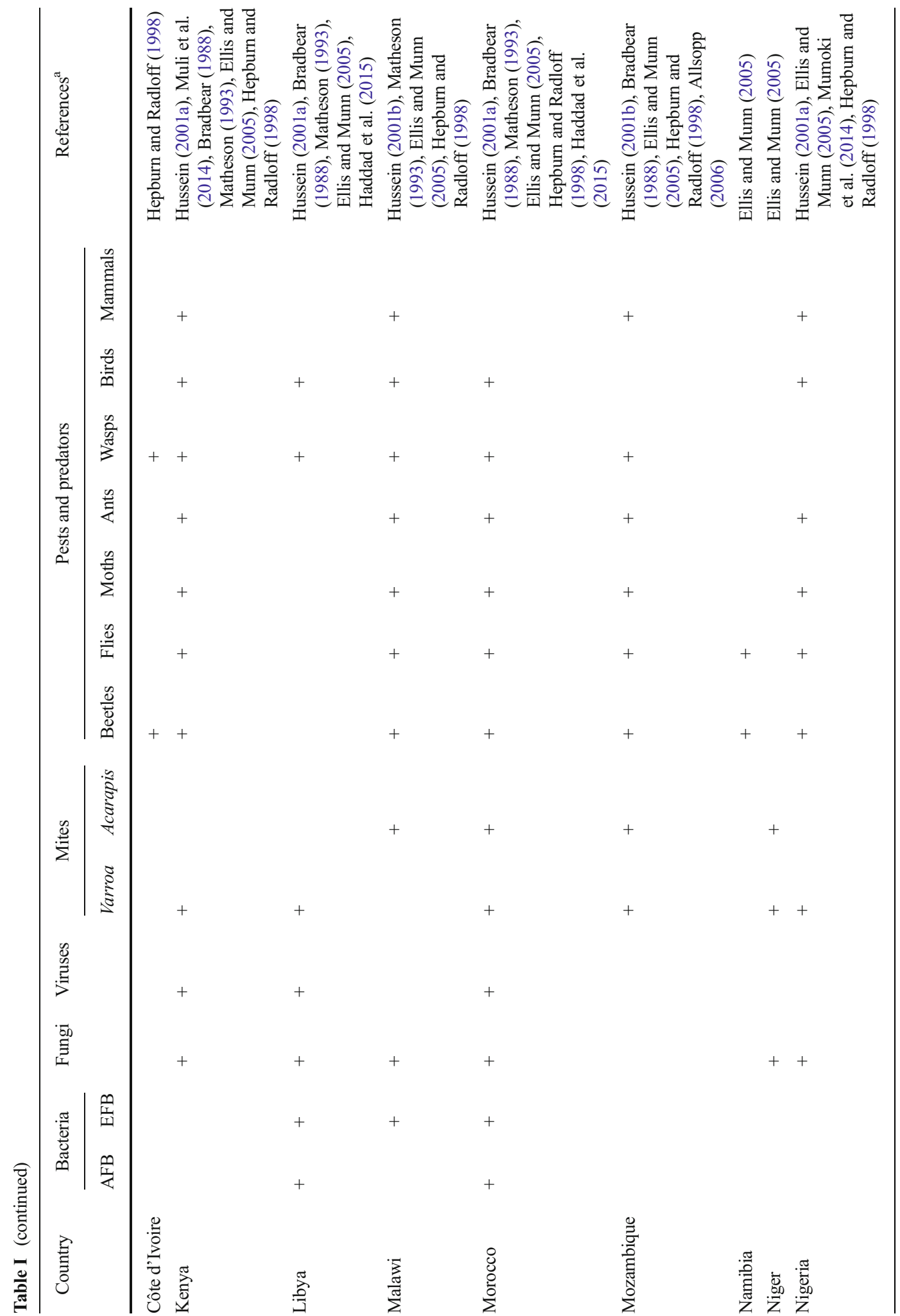




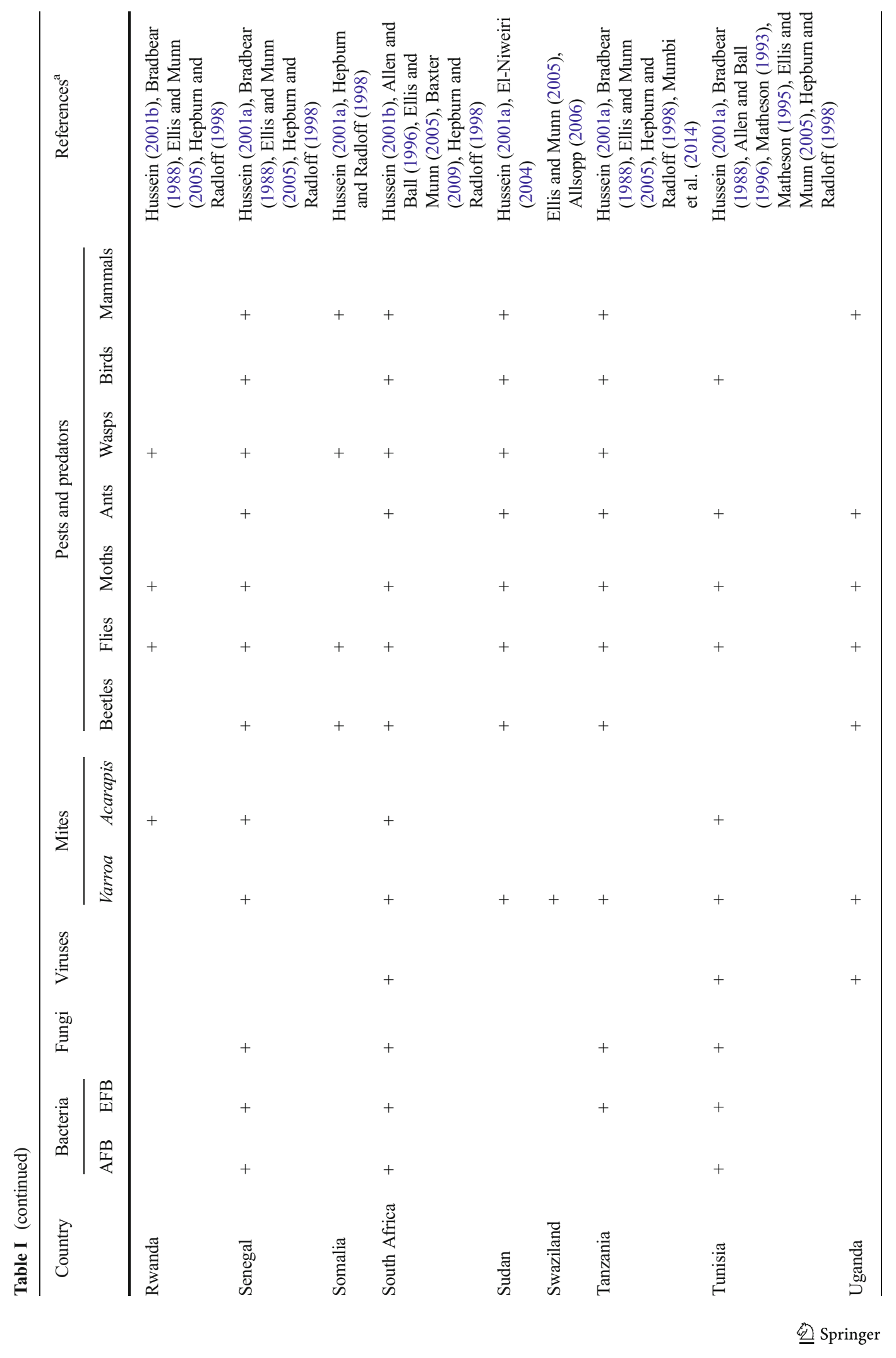




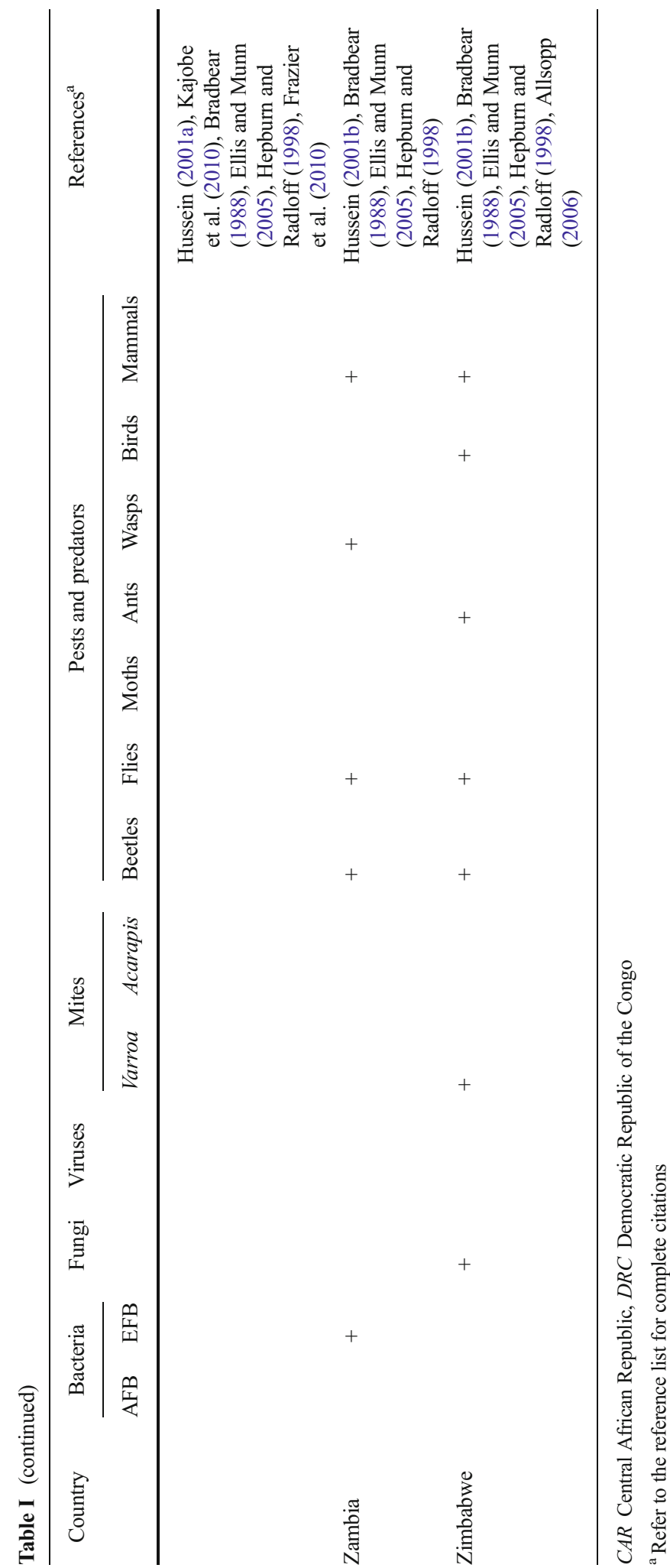




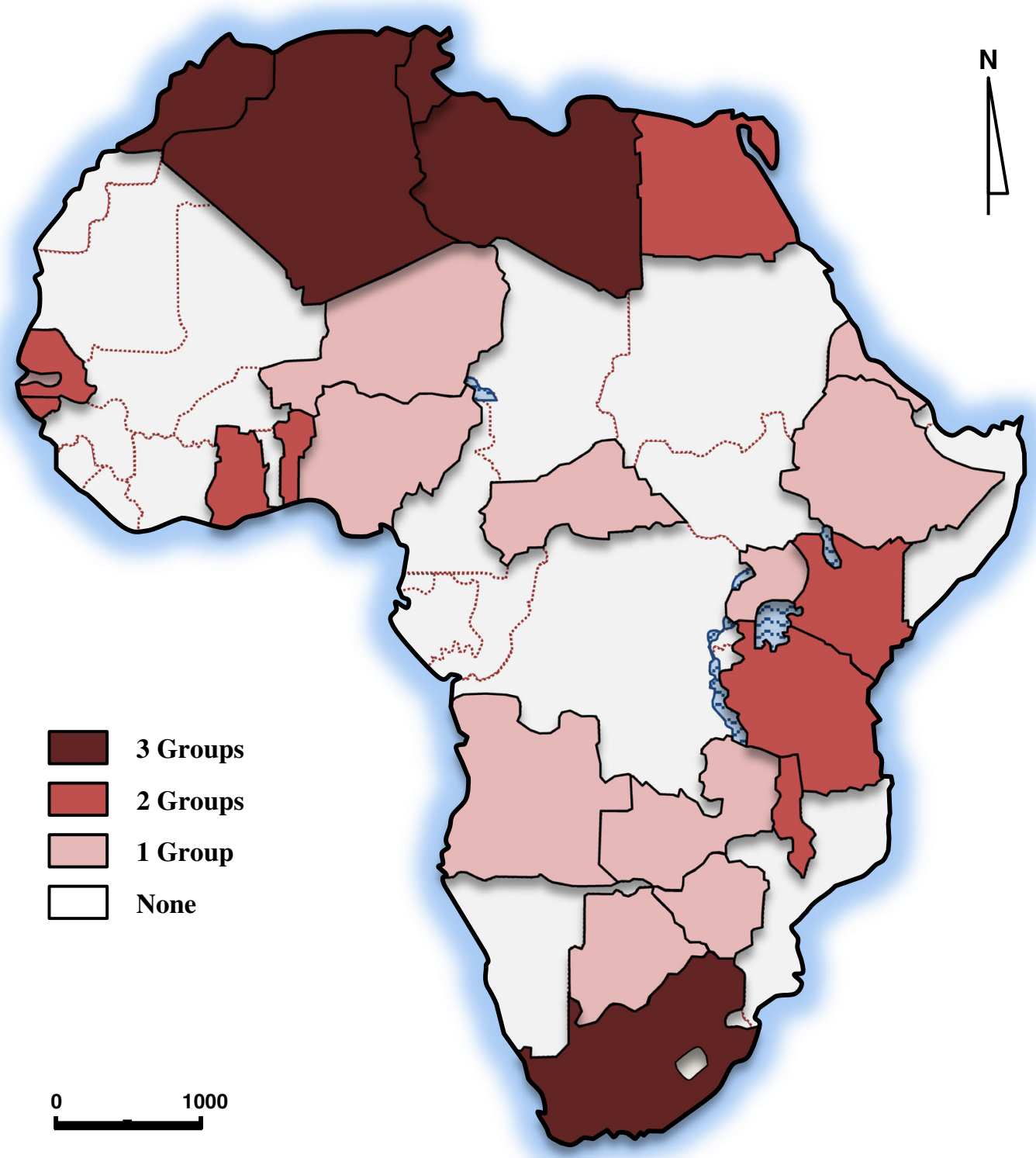

Figure 1. Distribution of pathogen groups (bacteria, fungi and viruses) associated with honeybees in Africa. The higher the numbers of groups present per country, the darker the shade; e.g. the darkest colour indicates the presence of bacteria, fungi and viruses. Countries depicted in white indicate no reported presence of pathogens or insufficient data (for detailed information, see Table I).

behaviour or reducing disease pressure by more frequent absconding (non-reproductive swarming; Hepburn and Radloff 1998 and references therein). However, currently in the
Western Cape of South Africa, it seems that AFB and the lack of good beekeeping practices used in that region have overburdened the managed honeybee population resulting in 


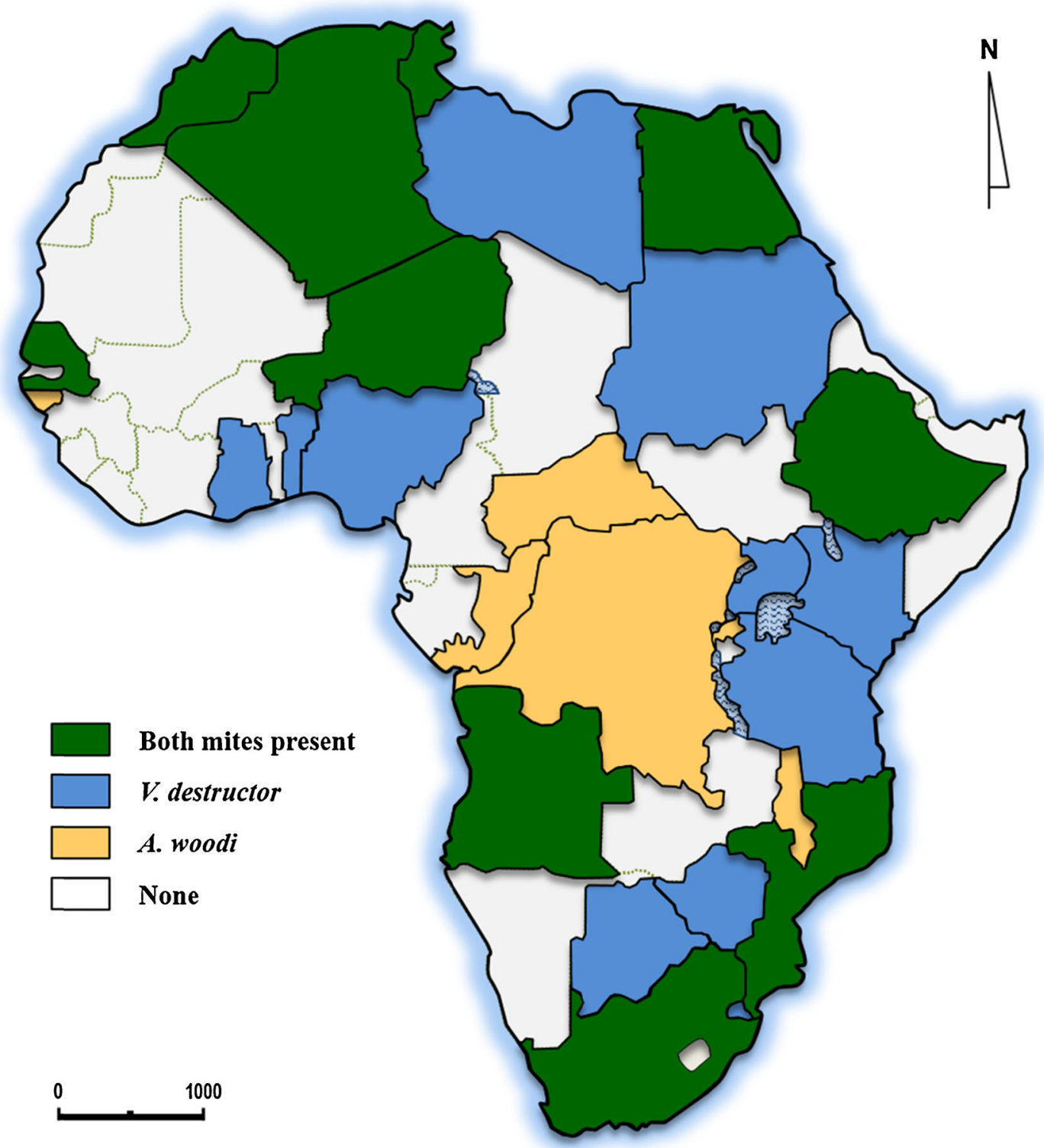

Figure 2. Distribution of parasites ( $V$. destructor and Acarapis woodi) associated with honeybees in Africa. Countries depicted in white indicate no reported presence of parasites or insufficient data (for detailed information see Table I).

significant colony losses (Kriel 2015). The spread of this disease into the wild population, in particular in rural underdeveloped areas on the African continent, may have severe implications for pollination (Kasina et al. 2009).

\subsubsection{European foulbrood (Melissococcus plutonius)}

The other major bacterial disease of honeybees, European foulbrood (EFB), is caused by 


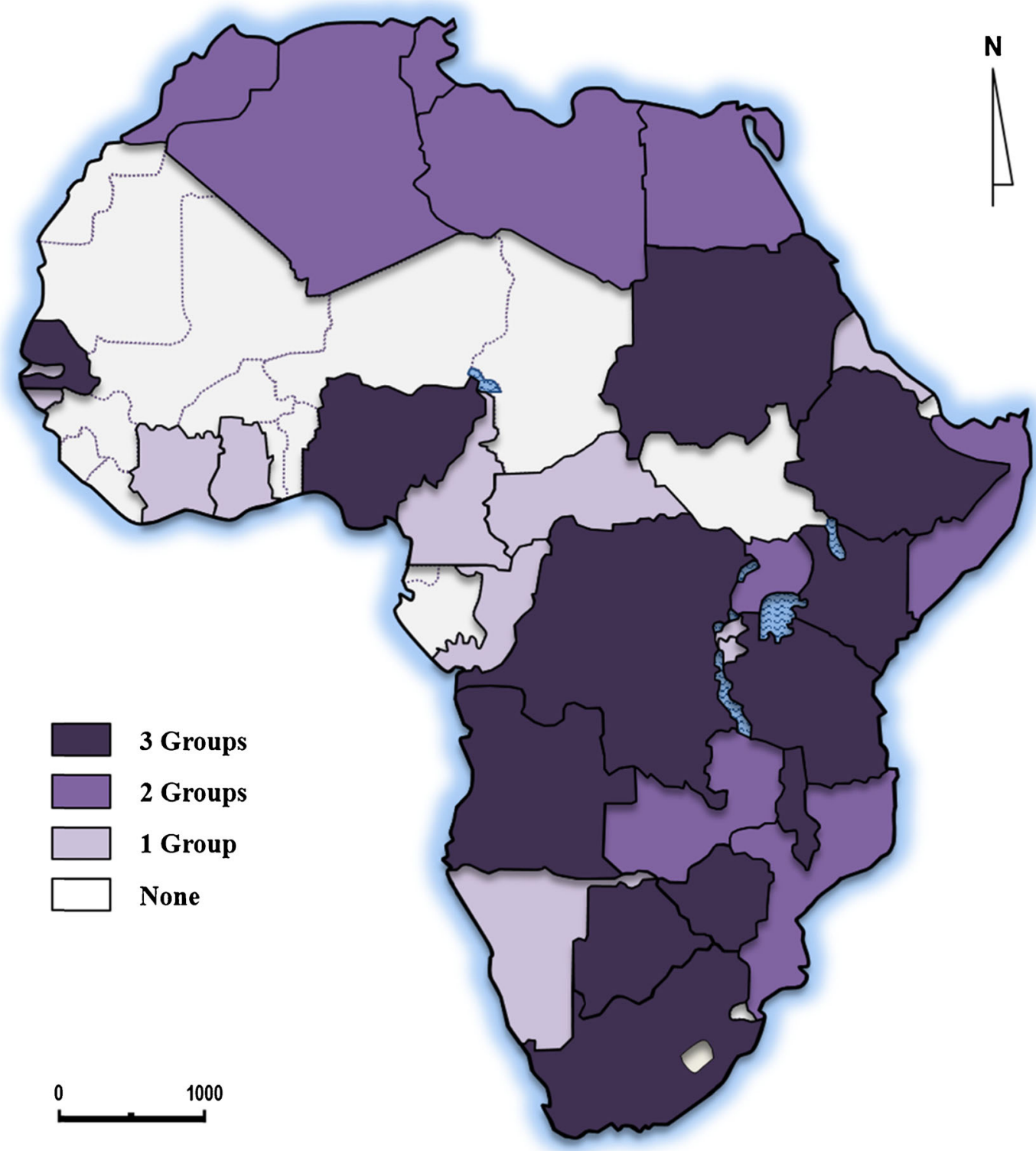

Figure 3. Distribution of pest and predator groups (insects, birds and mammals) associated with honeybees in Africa. The higher the numbers of groups present per country, the darker the shade; e.g. the darkest colour indicates the presence of insects, birds and mammals. Countries depicted in white indicate no reported presence of pests and predators or insufficient data (for detailed information, see Table I).

Melissococcus plutonius and is very prevalent in Africa (Matheson 1993; Hussein 2001a, b; Ellis and Munn 2005; Mumoki et al. 2014). EFB is also a notifiable disease of the OIE. EFB kills larvae before they are capped and disease outbreaks appear to be seasonal and stress related (Forsgren
2010). Even though this disease is considered to be less pathogenic than AFB, it may still result in economic colony losses (Forsgren et al. 2013). Despite the long history in Africa, significant losses have not been reported (Swart et al. 2001; Pirk et al. 2014). 


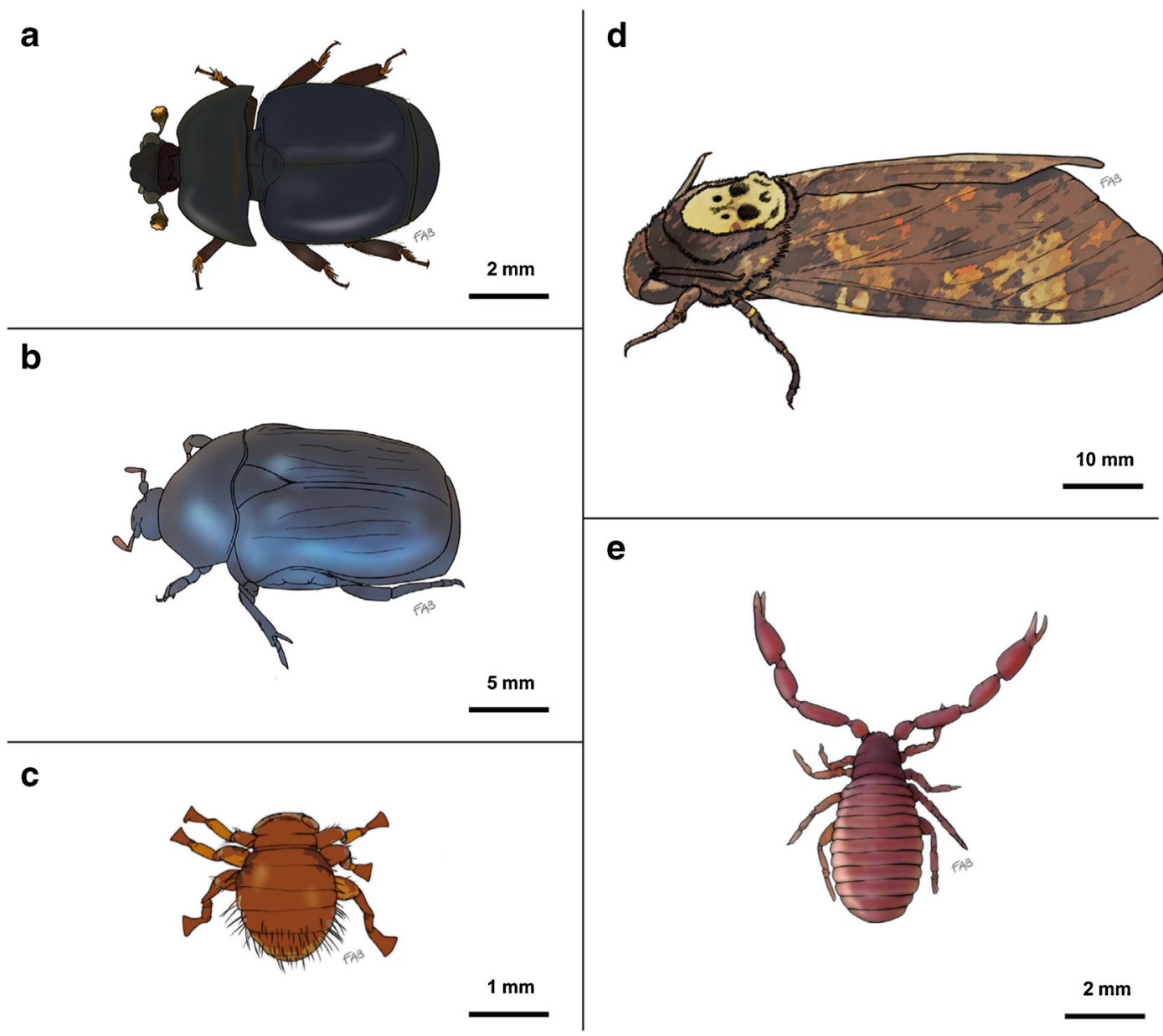

Figure 4. Drawings of interesting pests commonly found in South African colonies: a small hive beetle (Aethina tumida), b large hive beetle (Oplostomus fuligineus), c bee louse (Braula coeca), d death's head hawkmoth (Acherontia atropos), and e bee pseudoscorpion (Ellingsenius spp.). Drawings by Dr F. Démares (Adobe Photoshop CS2).

\subsection{Fungi}

\subsubsection{Nosema apis and N. ceranae}

There are many reports confirming the presence of N. apis (Hussein 2001a, b; Swart et al. 2001; Fries and Raina 2003; Ellis and Munn 2005; Strauss et al. 2013; Mumoki et al. 2014) in Africa, but there are only two reports of $N$. ceranae in colonies from Algeria and Benin (Higes et al. 2009; Cornelissen et al. 2011). $N$. apis and $N$. ceranae are microsporidian gut parasites that cause nosemosis in adult honeybees.
Symptoms produced by $N$. apis in honeybees (most often in spring) include trembling, crawling, inability to fly and spotting (dysentery) (Sammataro and Avitabile 2011). In contrast, $N$. ceranae does not produce obvious symptoms and is commonly found throughout the year (Bourgeois et al. 2010). Both Nosema species affect colony mortality rates, as well as honey and brood production (Fries 2010; Fries et al. 2013). Evidence with regards to the virulence, seasonality and overall effect of both $N$. apis and $N$. ceranae infection in honeybee colonies is contradictory (Williams et al. 2014; Milbrath 
et al. 2015; Natsopoulou et al. 2015). European honeybees have shown that the effects of both Nosema species depend on the honeybee subspecies and the strain of Nosema (Paxton et al. 2007; Martín-Hernández et al. 2011). Unfortunately, in Africa, there is limited knowledge of the occurrence and prevalence of both Nosema species; nevertheless, there is also a lack of reported negative impacts on African subspecies.

\subsubsection{Chalkbrood (Ascosphaera apis)}

Ascosphaera apis occurs in various countries in Africa, including Algeria, Tunisia, Egypt, Ethiopia, Nigeria and South Africa (Heath 1985; Hussein 2001a, b; Swart et al. 2001; Ellis and Munn 2005; Yohannes et al. 2009; Sanad and Mohanny 2011; Akinwande et al. 2013; Strauss et al. 2013). Chalkbrood is a fungal brood disease that affects larvae. The mummified larvae can easily be detected and vary in colour from white to black (reviewed in Aronstein and Murray 2010). In some cases, chalkbrood can cause a reduction in colony numbers and possibly colony losses (reviewed in Jensen et al. 2013). However, proper beekeeping practices (e.g. good ventilation) may limit the effects of this disease (Sammataro and Avitabile 2011).

\subsection{Viruses}

At present, there are at least 23 viruses associated with honeybee health (McMenamin and Genersch 2015), of which the presence of nine have been reported in many African countries. These viruses include Deformed wing virus (DWV), Black queen cell virus (BQCV), Varroa destructor virus 1 (VDV-1), Israeli acute paralysis virus (IAPV), Acute bee paralysis virus (ABPV), Chronic bee paralysis virus (CBPV), Apis mellifera filamentous virus (AmFV), Lake Sinai virus (LSV) and Sacbrood virus (SBV) (Allen and Ball 1996; Davison et al. 1999; Hussein 2001a; Kajobe et al. 2010; Loucif-Ayad et al. 2013; Strauss et al. 2013; Muli et al. 2014; Mumoki et al. 2014; Amakpe et al. 2015). Recently, five of the nine viruses mentioned above were extensively reviewed by Mumoki et al. (2014), and therefore, we will focus on the remaining four viruses namely, CBPV, VDV-1, AmFV and LSV. All four viruses appear to occur throughout the year and they mostly affect adult honeybees (de Miranda et al. 2013).

CBPV-infected honeybees can show either one of two distinct sets of symptoms: trembling, crawling, irregular wing position, stretched abdomens or black/greasy appearance (hairless) (Ribière et al. 2010). CBPV may affect all honeybee life stages and transmission of this virus is mostly horizontal with little information about vertical transmission routes (de Miranda et al. 2013).

VDV-1 is closely related to DWV and it has been suggested that VDV-1 can cause wing deformity in honeybees (Ongus 2006; Zioni et al. 2011). This virus affects larvae, pupae and adults, and transmission occurs through various pathways (de Miranda et al. 2013). The presence of this virus in Africa is of concern due to its known association with $V$. destructor (see Section 3.4.1).

AmFV does not cause noticeable symptoms in adult honeybees, but some of these honeybees when dissected may have white haemolymph (de Miranda et al. 2013). Although this virus has been reported all year round, it may be more prevalent during spring (de Miranda et al. 2013; Hartmann et al. 2015). Horizontal and vertical transmission routes exist and information with regards to its association with other pathogens (e.g. N. apis) is contradictory (Hartmann et al. 2015). The only positive confirmation of AmFV presence is from South Africa (Allen and Ball 1996); hence, the economic effect may be negligible. Furthermore, Hartmann et al. (2015) suggested that AmFV on its own should not have an impact at the colony level.

LSV has only recently been described in adult honeybees (Runckel et al. 2011) and was only found in three adult samples from Benin (Amakpe et al. 2015). The transmission routes and associations of this virus with other pathogens or parasites are unknown (de Miranda et al. 2013). For that reason, the economic importance of LSV in Africa requires further investigation but seems negligible at present.

In general, severe losses due to honeybee viruses have not been reported in Africa, but this 
may be due to a lack of knowledge, data collection/availability and virus primer specificity; the latter can be addressed by developing virus primers specifically for African honeybees. However, the presence of these viruses is of concern since they may cause stress which in combination with other factors (e.g. $V$. destructor or pesticides) may ultimately affect honeybee health.

\subsection{Parasitic mites}

\subsubsection{Varroa destructor}

$V$. destructor is one of the most well-known, economically important and widely distributed ectoparasites affecting honeybees (Rosenkranz et al. 2010) and is an OIE notifiable infestation. This mite was once confined to its natural host the Eastern honeybee, Apis cerana, but has since shifted its host to, among others, the Western honeybee (Donzé and Guerin 1994; Potts et al. 2010). V. destructor has been reported in many African countries (Hussein 2001a, b; Ellis and Munn 2005; Mumoki et al. 2014); however, this may be an underestimate due to the limited availability of data. Nonetheless, the reported presence of $V$. destructor in South Africa, Angola, Kenya, Egypt, Morocco, Senegal, Niger and Nigeria is distressing, as this indicates a wide geographical spread within the continent (Table I and Figure 2).

$V$. destructor mites feed on the haemolymph of honeybees (adults and developing brood) and reproduction takes place inside capped brood cells (Donzé and Guerin 1994). The duration of mite feeding during honeybee pupal development depends on the caste and sub-species (Rosenkranz et al. 2010). $V$. destructor mites have a preference for drone brood due to the longer post-capping stage, which allows for the production of a higher number of mated daughter mites (Fuchs 1990). Physiological parameters, flight behaviour and longevity of honeybees infested with mites during development or as adults can be negatively affected (Schneider and Drescher 1987; Bowen-Walker and Gunn 2001; Kralj and Fuchs 2006; Rosenkranz et al. 2010). In addition, $V$. destructor mites are capable of transmitting numerous viruses within and between colonies (Chen and Siede 2007; de Miranda et al. 2013).
Even though most of these viruses are present in Africa (see Section 3.3), there have been no reports of high colony losses directly linked to $V$. destructor mites and/or viruses (Muli et al. 2014; Pirk et al. 2014). The survival of African honeybee colonies in the presence of $V$. destructor, without chemical treatment, suggests that honeybees may not be as threatened in Africa or more resistant compared with other parts of the world.

\subsubsection{Tracheal mites (Acarapis woodi)}

The endoparasitic tracheal mite, Acarapis woodi, has been reported in most countries in Africa (Bradbear 1988; Hussein 2001a, b; Matheson 1993; Swart et al. 2001) and is an OIE notifiable infestation. Adult mites are found in the trachea of honeybees where they feed on haemolymph (Otis and Scott-Dupree 1992). Most of the damage attributed to these mites has been found in European sub-species of honeybees that overwinter, and include low honey production, increased mortality rates and reduced honeybee lifespans (Eischen et al. 1989; Otis and ScottDupree 1992; Sammataro et al. 2013). In Africa, overwintering does not occur at the same scale, and for that reason, mite infestations may not result in the same damage mentioned above. The continuous presence of newly emerged African honeybees may be ideal for these mite populations to grow. However, very little data exist on the effect and presence of these mites in African honeybee colonies, and more research is required to determine whether these mites may pose a threat. This also applies to other honeybee mites such as Tropilaelaps spp. (Asian origin). These mites have only been reported in Kenya (Kumar et al. 1993), but there are doubts as to whether the identification of the sample was accurate (Anderson and Roberts 2013).

\subsection{Associated honeybee pests and predators}

\subsubsection{Coleoptera (beetles)}

Small hive beetles (SHB) (Aethina tumida) The natural distribution of Aethina tumida (SHB) is 
limited to sub-Saharan Africa, where SHB are considered to be a negligible pest (Lundie 1940; Hepburn and Radloff 1998) (Figure 4a). However, infestation with SHB is listed by the OIE as a notifiable infestation. Adult beetles and larvae reside within the honeybee colony and cause damage to brood, pollen and honey which they feed upon (Elzen et al. 1999). In North Africa, the introduction of SHB into Egypt did not have significant negative impacts, and SHB populations remain low (El-Niweiri et al. 2008) or absent (Hassan and Neumann 2008) in local honeybee colonies. Devastating effects have been reported in countries outside of Africa (Australia and the USA) where the beetles have been introduced (Neumann and Elzen 2004). From an African perspective, the beetles do not seem to pose a significant threat to beekeeping; however, the fact that they can act as vectors of honeybee viruses and bacteria should be of concern (Eyer et al. 2009; Schäfer et al. 2010). Since SHB are endemic to parts of Africa, it seems that honeybees have co-evolved with this particular pest.

Large hive beetles The African continent is home to numerous large hive beetles (Cetoniids, e.g. Oplostomus fuligineus, Oplostomus haroldi) that can invade honeybee colonies (Hepburn and Radloff 1998; Fombong et al. 2013) (Figure 4b). Adult beetles consume food stores as well as honeybee brood (Swart et al. 2001). These beetles can become problematic if present in large numbers, but in general, they are not considered to be serious pests of honeybee colonies in Africa.

\subsubsection{Diptera (flies)}

Tachinid fly (Rondanioestrus apivorus) In the family Tachinidae, $R$. apivorus, is the only species known to parasitise honeybees; specimens have been collected in southern Africa and Uganda (Knutson and Murphy 1990; Hepburn and Radloff 1998). Female flies deposit larvae on the abdomens of their hosts, which allows immediate penetration into the honeybee (Skaife 1920; Fletcher 1978). Larval growth inside the honeybee is quick, and after 4 weeks, the larva (with two distinctive black spiracles) is ready to emerge from the adult honeybee. Pupation occurs in the soil and adult flies are fully developed after approximately 10 days (Knutson and Murphy 1990). The distribution of these flies in Africa is limited, and according to Skaife (1920) and Anderson et al. (1983), only 3 and $5 \%$ of adult honeybees are parasitised, respectively. However, in rare circumstances, infestation levels of up to $30 \%$ have also been reported (Anderson et al. 1983). This fly seems to be of little economic importance for African honeybee health, due to the low parasite levels and a lack of recent data.

\section{Bee conopid (Physocephala spp.) Physocephala} is another fly genus (wasp-like appearance) that parasitises honeybees in a similar manner to $R$. apivorus, and they are also limited to southern Africa and Uganda (see above); the only difference being that larvae pupate inside the honeybee's abdomen (Anderson et al. 1983). Mature larvae and pupae can be distinguished from $R$. apivorus by their spike-like spiracles (Swart et al. 2001). These flies are only noticed occasionally and the levels of infestation vary; therefore, they seem to pose no threat to African honeybee health (Knutson and Murphy 1990).

Bee louse (Braula spp.) Braula, or the bee louse, is a tiny wingless fly (Hepburn 1978) which used to have a global distribution (Ellis and Munn 2005) (Figure 4c). In the past few decades, the chemical treatment of $V$. destructor has had a detrimental effect on bee louse populations (Kulincevic et al. 1991; Sammataro and Avitabile 2011) and may have reduced their distribution to areas such as Africa where mite treatment is not used (Hepburn and Radloff 1998; Hussein 2001a, b; Strauss et al. 2014). Bee lice usually attach themselves to an adult honeybee and steal food out of the mouths of their hosts (Knutson and Murphy 1990). Although opinions differ regarding the status of adult Braula as a parasite, some maintain that bee lice cause little or no harm to honeybee colonies apart from consuming honey and pollen stores (Hepburn 1978). However, bee lice have been reported to disfigure honey combs, cause paralysis or death of developing honeybees and decrease the queen's egg laying efficiency (Argo 1926; Hepburn 1978; 
Knutson and Murphy 1990; Marcangeli et al. 1993; Zaitoun and Al-Ghzawi 2008). At low infestation levels, the impact of Braula spp. is negligible in honeybee colonies and they should not affect colony health in Africa. However, their potential as vectors of viruses and other diseases still has to be evaluated.

\subsubsection{Lepidoptera (moths)}

Wax moth (Galleria mellonella and Achrola grisella) Galleria mellonella (greater wax moth) and Achrola grisella (lesser wax moth) are common in honeybee colonies throughout Africa, with the greater wax moth being more prevalent and damaging (Hepburn and Radloff 1998; Hussein 2001a, b; Swart et al. 2001; Lawal and Banjo 2007; Oyerinde and Ande 2009). Wax moth larvae are considered to be "hive cleaners" since they consume all the remaining comb and stores once the honeybees have absconded (Fletcher 1978). However, larvae can cause destruction when they tunnel through the brood and honey comb and wooden parts of the hive (Hepburn and Radloff 1998). In addition to the physical damage caused, larval tunnelling can result in galleriasis and bald brood (Ellis et al. 2013). Wax moth damage is most pronounced in weak or stressed colonies, and therefore, good management practices are essential to minimise damage and colony losses (Swart et al. 2001). So far, they are not a threat to African honeybees and it is unlikely that they may become a threat.

\section{Death's head hawkmoth (Acherontia atropos)} Acherontia atropos is found throughout Africa and the adult moth is easily identified by the distinct skull design on its thorax (Hepburn and Radloff 1998; Picker et al. 2004; Lawal and Banjo 2007; Zagorinsky et al. 2012) (Figure 4d). They are known to invade honeybee colonies in search of honey (Moritz et al. 1991; Kitching 2003). The unique characteristics of these moths are their ability to not only imitate the piping sounds of the queen but also to use chemical camouflage which prevent them from being attacked by workers (Moritz et al. 1991). Compared to the wax moths (see above), death's head hawkmoths only consume honey/nectar and do not cause any obvious damage in the colony (Swart et al. 2001). As a result, they are not considered to be harmful or of any economic importance.

\subsubsection{Hymenoptera (ants, wasps and honeybees)}

Ants Various ant species (e.g. Anoplolepis custodiens, Linepithema humile, Pheidole megacephala, Dorylus fulvus), either native or introduced to Africa, have been reported in honeybee colonies (Hepburn and Radloff 1998; Hussein 2001a, b; Swart et al. 2001; Begna 2007). Ants are known to enter honeybee colonies and remove food stores and brood, and their continued disturbance can cause colonies to abscond (Swart et al. 2001). The invasion of colonies by ants has the potential to cause serious economic losses to the beekeeper: both through the loss of hive products and most importantly the colony itself.

Wasps Bee pirates (Palarus latifrons, Philanthus triangulum )

Palarus latifrons (banded bee pirate) and Philanthus triangulum (yellow bee pirate) can be found in Africa (Hepburn and Radloff 1998; O’Neill 2008). They are considered to be active predators that capture honeybees either as a food source for themselves or provisioning for their young (Fletcher 1978; Swart et al. 2001). Palarus latifrons hunt honeybees at the hive entrance, while Philanthus triangulum capture them while they are foraging (Anderson et al. 1983). The aggressive behaviour of the wasps can prevent honeybees from leaving the hive to forage, and this may affect colony productivity and reduce honeybee numbers (O’Neill 2008).

German yellow jacket (Vespula germanica)

Vespula germanica, is native to northern Africa, but has been introduced into the western parts of South Africa (Archer 1998; Tribe and Richardson 1994). These social wasps are opportunistic predators that feed on a range of invertebrates, including honeybees, as well as nectar and honey (Masciocchi et al. 2010). They have been observed to feed on dead honeybees and typically 
only carry bee body parts back to their nests (Coelho and Hoagland 1995). It seems as though they do not pose a significant risk to honeybee numbers, but they can threaten other native wasp species when competing for nesting areas and food (Tribe and Richardson 1994).

\subsubsection{Honeybees}

Apis mellifera capensis social parasite A unique problem facing South African beekeepers is the human-facilitated invasion of $A$. mellifera capensis into the natural range of the other subspecies, A. mellifera scutellata (Hepburn and Allsopp 1994; Hepburn and Radloff 1998; Oldroyd 2002). Upon entering A. m. scutellata colonies, $A$. m. capensis workers, which have the predisposition to become social parasites (Zheng et al. 2010), compete for reproduction. A. m. capensis workers are able to lay diploid eggs and produce queen-like signals (Onions 1912; Martin et al. 2002; Neumann and Moritz 2002; Pirk et al. 2012). These A. mellifera capensis social parasites do not contribute to the work force and their offspring do not replace the host workers, but these social parasites and their clonal offspring just reproduce which then results in the collapse of the host colony (Hillesheim et al. 1989; Neumann et al. 2001; Moritz 2002; Neumann and Hepburn 2002). This parasite is spread by migratory beekeepers during pollination and has resulted in large-scale colony losses with significant economic implications for the South African beekeeping industry (Allsopp and Crewe 1993; Johannsmeier 1994; Moritz 2002; Kryger et al. 2003; Dietemann et al. 2006; Pirk et al. 2014). The problem is still ongoing after 25 years.

Dwarf honeybee (Apis florea) A. florea, native to Asia, was first detected in Khartoum, Sudan, in 1985 (Lord and Nagi 1987; Mogga and Ruttner 1988; Radloff et al. 2011). A. florea has gradually expanded its distribution to the whole of Sudan (Moritz et al. 2010b) and to neighbouring countries such as Ethiopia (Bezabih et al. 2014). Since the climate and floral conditions are similar to their natural distribution range (Radloff et al. 2011), the species may easily colonise the whole continent.
With respect to pollination, the competition for pollen between the native $A$. mellifera sudanensis and A. florea seems to be limited, suggesting that the impact on native Apis species will be minor (El Shafie et al. 2002; Bezabih et al. 2014).

\subsubsection{Bee pseudoscorpion (Ellingsenius spp.)}

Bee pseudoscorpions (Class: Arachnida) are widely distributed throughout Africa with eight species described (Judson 1990) (Figure 4e). Bee pseudoscorpions (not true scorpions) are small in size with large pincers (Judson 1990). Their diet is restricted to biological detritus (Thapa et al. 2013), and thus, they are considered to be harmless in honeybee colonies (Allsopp et al. 2003).

\subsubsection{Birds and mammals}

Various birds and mammals (e.g. humans, honey badgers, baboons, monkeys, mice), associated with or damaging to honeybee colonies, are common throughout Africa (Crane 1999; Hepburn and Radloff 1998; Hussein 2001a, b).

The most well-known birds associated with honeybees are bee-eaters (Meropidae), honeyguides (Indicatoridae) and drongos (Dicruridae). Honey-guides are widely known for guiding animals (e.g. baboons and honey badgers) to honeybee nests (Crane 1999). They do not feed on honeybees but consume wax that remains after the nest has been robbed and/or damaged by the guided mammal (Swart et al. 2001). Bee-eaters and drongos prey on honeybees and remove the sting/venom prior to ingestion, and severe predation by these birds can cause honeybees to stop foraging (Hepburn and Radloff 1998). Among these birds, bee-eaters are considered to be the most damaging to honeybee colonies since a single bird can devour up to 600 honeybees on a daily basis (Hepburn and Radloff 1998).

Of the mammals, the most destructive are honey badgers and humans. Honey badgers (Mellivora capensis) are nocturnal mammals with powerful claws that they use for digging, climbing and breaking hives open (Hepburn and Radloff 1998). Their destructive behaviour results in the loss of colonies. Damage caused by humans 
includes total destruction of colonies (e.g. traditional honey hunting), vandalism, fire, theft and even intentional poisoning of honeybee colonies (Crane 1999; Hussein 2001a, b; Swart et al. 2001; Dietemann et al. 2009).

\section{PESTICIDES}

The increased demand for food security in developing countries has resulted in increased crop production and subsequently a greater use of agrochemicals. Pesticides, in particular, can have a negative and harmful impact on the behaviour and physiology of honeybees that can directly influence the overall health of the colony (Yang et al. 2008; Di Prisco et al. 2013; Williamson and Wright 2013; Smith et al. 2013). These negative effects can become even more pronounced when honeybees are simultaneously exposed to multiple stressors, i.e. pathogens or parasites (Vidau et al. 2011; Köhler et al. 2012). Pettis et al. (2012) reported a higher infection of Nosema species in honeybees exposed to neonicotinoids, while Aufauvre et al. (2012) demonstrated the impact of multiple exposure to both parasites and pesticides. However, under field conditions, Retschnig et al. (2015) found no interactions between $N$. ceranae and neonicotinoid pesticides, and therefore, more studies under natural situations are necessary before definitive conclusions can be made.

Limited studies are available on the impacts of pesticides on African honeybees. In addition, the focus tends to be on pesticides used for agricultural crops, but in Africa, the use of pesticides to control mosquitoes (malaria vectors) may also affect honeybees negatively (Munyuli 2011). Most of the studies on pesticide use in Africa are laboratory based. In South Africa, Human et al. (2014) investigated the influence of nicotine (non-synthetic pesticide) on A. mellifera scutellata brood and found no negative impact. In adult $A$. mellifera scutellata, however, Köhler et al. (2012) found that multiple stressors (nicotine and Escherichia coli) affected survival despite them showing active detoxification (du Rand et al. 2015). Al Naggar et al. (2015) found that while pesticides are widely used in Egypt, they show little or no effect on the local honeybee population. The reported low levels of pesticide residues in comb and bee bread found in
Kenya compared to those of colonies in the USA suggest that pesticide use may still be less intense in Africa (Muli et al. 2014). The effects of pesticides and the role they play in colony losses of honeybees in Africa need to be investigated further.

\section{FLORAL RESOURCES AND HABITAT TRANSFORMATION}

Hepburn and Radloff (1998) gave a detailed description of bee plants, floral resources, altitude and vegetation types on the African continent. For example, in southern Africa, $80 \%$ of its extremely rich flora is endemic and hosts an impressive diversity of pollinators (Cowling et al. 1997). A large number of these plants are important for honeybees (Hepburn and Radloff 1998).

Africa's unique biodiversity may be at risk due to an increase in the human population that results in higher rates of deforestation and substantial changes in natural landscapes (Norris et al. 2010; Abrol 2012). Reasons for deforestation include urbanisation (building of infrastructure), mining and agricultural development (including plantations, logging and crop production) (Duveiller et al. 2008; Munyuli 2011). All the abovementioned causes can result in habitat loss and fragmentation that may affect various pollinators, including honeybees (Donaldson et al. 2002; Brown and Paxton 2009; Dietemann et al. 2009; Munyuli 2011; Goulson et al. 2015). In particular, the transition from natural to agricultural farmland and the planting of monocultures change floral diversity and may impact the nutritional requirements and fitness of honeybees (Johannsmeier and Mostert 2001; Murray et al. 2009; Goulson et al. 2015). Indeed, genetic diversity of the honeybee population is reduced in agricultural vs. natural areas (Jaffé et al. 2010). Even in agriculturally utilised land, pollination success is dependent on pollinator diversity (Carvalheiro et al. 2011). Moreover, honeybees actively regulate their nutritional intake (Altaye et al. 2010; Pirk et al. 2010). If they are unable to meet their nutritional demands, due to deficient pollen and nectar resources, worker survival, colony health and development may be negatively affected (Brodschneider and Crailsheim 2010; Goulson et al. 2015). 


\section{CONCLUSION}

The recent decline in honeybee populations and the demand for sustainable pollination to ensure food security have resulted in increased awareness of the need to protect honeybee populations, especially in Africa (Dietemann et al. 2009). There is a need to initiate an African database (similar to that of the OIE) for the presence of pathogens, parasites, pests and predators.

Increased research has to focus on the underlying mechanisms of potential resistance of African honeybees. To ensure a healthy honeybee population, early identification of possible threats is vital. One of the recent outcomes is the establishment of the African Reference Laboratory for Bee Health, situated at the International Centre of Insect Physiology and Ecology (icipe) in Kenya to improve knowledge of honeybee health in East Africa (AU-IBAR Press Release 2014).

Moreover, active efforts to continually monitor pollinators are very important in the prevention of a pollination calamity (Goulson et al. 2015) and will help to reduce knowledge gaps on pollinator systems in Africa (Archer et al. 2014). Research on the role and importance of pollination systems in Africa is lacking, especially when compared with global data (Archer et al. 2014). We also need to prevent further introduction of any biological agents that may negatively affect natural honeybee and other pollinator populations (Dietemann et al. 2009; Munyuli 2011). Furthermore, education of the general public on the conservation of honeybee plants and nesting sites is of utmost importance. More specifically, beekeepers (commercial, developmental and hobbyist) need to be properly trained in beekeeping management and hive biology, ultimately resulting in the minimisation of colony stress (Dietemann et al. 2006, 2009).

Honeybee populations in Africa may have a natural mechanism of resilience against many of the introduced pathogens and parasites (Pirk et al. 2014). Compared to European honeybees, African populations are genetically diverse (due to the large wild population), have higher swarming rates and smaller colonies and are less commercialised (Hepburn and Radloff 1998; Schneider et al. 2004; Dietemann et al. 2009; Wallberg et al. 2014). In addition, colonies in Africa are known for their absconding behaviour in response to unfavourable conditions, continued disturbance and the presence of pathogens, parasites, pests or predators (Fletcher 1978; Hepburn and Radloff 1998; Fries and Raina 2003). All of these factors may contribute to reducing the impact of stressors on honeybee health in Africa. Even though African honeybee populations have not been impacted by the losses as recorded in Europe and the USA (vanEngelsdorp and Meixner 2010; Pirk et al. 2014), there is a need to take precautionary measures to protect and conserve them and their habitat.

\section{ACKNOWLEDGMENTS}

Funding was provided by the South African National Research Foundation (NRF) and the University of Pretoria. We thank the reviewers for constructive comments, Kendall Richardson and Robin Crewe for proofreading a later version of the manuscript, and Chamanti Laing for supplying pictures for the drawings.

La santé des abeilles en Afrique: une synthèse

Apidae / Afrique / pathogène / ravageur / prédateur / perte d'habitats

Bienengesundheit in Afrika - ein Review

Honigbienen / Afrika / Bienengesundheit / Krankheitserreger / Parasiten / Schädlinge / Prädatoren / Habitatverlust

\section{REFERENCES}

Abrol, D.P. (2012) The role of pollination in improving food security and livelihoods. In: Abrol, D.P. (ed.) Pollination biology: Biodiversity conservation and agricultural production, pp. 737-770. Springer Verlag, Berlin

Aebi, A., Vaissière, B.E., vanEngelsdorp, D., Delaplane, K.S., Roubik, D.W., Neumann, P. (2012) Back to the 
future: Apis versus non-Apis pollination-a response to Ollerton et al. Trends Ecol. Evol. 27 (3), 142-143

Aizen, M.A., Harder, L.D. (2009) The global stock of domesticated honey bees is growing slower than agricultural demand for pollination. Curr. Biol. 19(11), 915-918

Akinwande, K.L., Badejo, M.A., Ogbogu, S.S. (2013) Challenges associated with the honey bee (Apis mellifera adansonii) colonies establishment in south western Nigeria. Afr. J. Food Agric. Nutr. Dev. 13, 7467-7484

Al Naggar, Y., Codling, G., Vogt, A., Naiem, E., Mona, M., Seif, A., Giesy, J.P. (2015) Organophosphorus insecticides in honey, pollen and bees (Apis mellifera L.) and their potential hazard to bee colonies in Egypt. Ecotoxicol. Environ. Saf. 114, 1-8

Al-Ghamdi, A.A., Nuru, A., Khanbash, M.S., Smith, D.R. (2013) Geographical distribution and population variation of Apis mellifera jemenitica Ruttner. J. Apic. Res. 52, 124-133

Allen, M., Ball, B. (1996) The incidence and world distribution of honey bee viruses. Bee World 77 (3), 141-162

Allsopp, M. (2006) Analysis of Varroa destructor infestation of southern African honeybee populations. MSc-thesis, University of Pretoria, Pretoria, South Africa

Allsopp, M.H., Crewe, R.M. (1993) The Cape bee as a Trojan horse rather than the hordes of Genghis Khan. Am. Bee. J. 133, 121-123

Allsopp, M.H., Kassimatis, E.J., Swart, D.J., Dippenaar-Schoeman, A.S. (2003) No evidence that pseudoscorpions are controlling Varroa mites in South African honeybee colonies. S. Afr. Bee J. 75, 61-66

Allsopp, M.H., de Lange, W.J., Veldtman, R. (2008) Valuing insect pollination services with cost of replacement. PLoS One 3, e3128

Altaye, S.Z., Pirk, C.W.W., Crewe, R.M., Nicolson, S.W. (2010) Convergence of carbohydrate-biased intake targets in caged worker honeybees fed different protein sources. J. Exp. Biol. 213 (19), 3311-3318

Amakpe, F., De Smet, L., Brunain, M., Ravoet, J., Jacobs, F.J., Reybroeck, W., Sinsin, B., de Graaf, D.C. (2015) Discovery of Lake Sinai virus and an unusual strain of acute bee paralysis virus in West African apiaries. Apidologie . doi:10.1007/s13592-015-0372-Z

Anderson, D.L., Roberts, J.M.K. (2013) Standard methods for Tropilaelaps mites research, in: Dietemann, V., Ellis, J.D. and Neumann, P. (Eds.), The COLOSS BEEBOOK, Volume II: standard methods for Apis mellifera pest and pathogen research. J. Apic. Res. 52 (4). doi:10.3896/IBRA.1.52.4.21

Anderson, R.H., Buys, B., Johannsmeier, M.F. (1983) Beekeeping in South Africa. Departmental of Agricultural Technical Services. Bulletin no. 394
Archer, M.E. (1998) The world distribution of the EuroAsian species of Paravespula (Hym., Vespinae). Entomol. Mon. Mag. 134, 279-284

Archer, C.R., Pirk, C.W.W., Carvalheiro, L.G., Nicolson, S.W. (2014) Economic and ecological implications of geographic bias in pollinator ecology in the light of pollinator declines. Oikos 123, 401-407

Argo, V.N. (1926) Braula coeca in Maryland. J. Econ. Entomol. 19, 170-174

Aronstein, K.A., Murray, K.D. (2010) Chalkbrood disease in honey bees. J. Invertebr. Pathol. 103, S20-S29

AU-IBAR Press Release (2014) Launch of the African reference laboratory for bee health at the International Centre of Insect Physiology and Ecology (icipe), Nairobi, Kenya

Aufauvre, J., Biron, D.G., Vidau, C., Fontbonne, R., Roudel, M., Diogon, M., Viguès, B., Belzunces, L.P., Delbac, F., Blot, N. (2012) Parasite-insecticide interactions: a case study of Nosema ceranae and fipronil synergy on honeybee. Sci. Rep. 2, 326

Baxter, A. (2009) American foulbrood (AFB) in the Western Cape: advisory notice. S. Afr. Bee J. 81 , 8-9

Begna, D. (2007) Assessment of the effect of ant (Dorylus fulvus) on honeybee colony (A. mellifera) and their products in West \& South-West Shewa Zones, Ethiopia. Ethiop. J. Anim. Prod. 7, 12-26

Begna, D. (2014) Occurrences and distributions of honeybee (Apis mellifera jemenitica) Varroa mite (Varroa destructor ) in Tigray region, Ethiopia. J. Fish. Livest. Prod. 2, 126

Bezabih, G., Adgaba, N., Hepburn, H.R., Pirk, C.W.W. (2014) The territorial invasion of Apis florea in Africa. Afr. Entomol. 22 (4), 888-890

Bouga, M., Alaux, C., Bienkowska, M., Büchler, R., Carreck, N.L., et al. (2011) A review of methods for discrimination of honey bee populations as applied to European beekeeping. J. Apic. Res. 50, 51-84

Bourgeois, A.L., Rinderer, T.E., Beaman, L.D., Danka, R.G. (2010) Genetic detection and quantification of Nosema apis and $N$. ceranae in the honey bee. J. Invertebr. Pathol. 103 (1), 53-58

Bowen-Walker, P.L., Gunn, A. (2001) The effect of the ectoparasitic mite, Varroa destructor on adult worker honeybee (Apis mellifera) emergence weights, water, protein, carbohydrate, and lipid levels. Entomol. Exp. Appl. 101, 207-217

Bradbear, N. (1988) World distribution of major honeybee diseases and pests. Bee World 69(1), 15-39

Brodschneider, R., Crailsheim, K. (2010) Nutrition and health in honey bees. Apidologie 41, 278-294

Brown, M.J., Paxton, R.J. (2009) The conservation of bees: A global perspective. Apidologie 40 (3), 410-416

Carvalheiro, L.G., Veldtman, R., Shenkute, A.G., Tesfay, G.B., Pirk, C.W.W., Donaldson, J.S., Nicolson, S.W. 
(2011) Natural and within-farmland biodiversity enhances crop productivity: Weeds maximize nature benefits to crops. Ecol. Lett. 14, 251-259

Chen, Y.-P., Siede, R. (2007) Honey bee viruses. Adv. Virus Res. 70, 33-80

Coelho, J.R., Hoagland, J. (1995) Load-lifting capacities of three species of yellowjackets (Vespula) foraging on honey-bee corpses. Funct. Ecol. 9, 171-174

Cornelissen, B., Paraïso, A., van Hoof, R. (2011) Bee diseases new to sub-Saharan Africa found in Benin, Inter. Beekeeping Congr., Apimondia, Buenos Aires, Argentina

Cowling, R.M., Richardson, D.M., Schulze, R.E., Hoffman, M.T., Midgley, J.J., Hilton-Taylor, C. (1997) Species diversity at the regional scale. In: Cowling, R.M., Richardson, D.M., Pierce, S.M. (eds.) Vegetation of Southern Africa, pp. 447-473. Cambridge University Press, Cambridge

Crane, E. (1999) The World History of Beekeeping and Honey Hunting. Gerald Duckworth \& Co. Ltd., London

da Silva, F.L., Grassi Sella, M.L., Francoy, T.M., Costa, A.H.R. (2015) Evaluating classification and feature selection techniques for honeybee subspecies identification using wing images. Comput. Electron. Agric. $114,68-77$

Davison, S., Govan, D., Leat, V., Allsopp, M.H. (1999) Bee diseases in South Africa I: EFB, AFB, chalkbrood and bee viruses. S. Afr. Bee J. 71, 84-87

de Miranda, J.R., Bailey, L., Ball, B.V., Blanchard, P., Budge, G.E. (2013) Standard methods for virus research, in: Apis mellifera, in: Dietemann, V., Ellis, J.D. and Neumann, P. (Eds.), The COLOSS BEEBOOK, Volume II: standard methods for Apis mellifera pest and pathogen research. J. Apic. Res. 52 (4). doi:10.3896/IBRA.1.52.4.22

Di Prisco, G., Cavaliere, V., Annoscia, D., Varricchio, P., Caprio, E., Nazzi, F., Gargiulo, G., Pennacchio, F. (2013) Neonicotinoid clothianidin adversely affects insect immunity and promotes replication of a viral pathogen in honey bees. Proc. Natl. Acad. Sci. 110, 18466-18471

Dietemann, V., Lubbe, A., Crewe, R.M. (2006) Human factors facilitating the spread of a parasitic honey bee in South Africa. J. Econ. Entomol. 99(1), 7-13

Dietemann, V., Pirk, C.W.W., Crewe, R.M. (2009) Is there a need for conservation of honeybees in Africa? Apidologie 40, 285-295

Donaldson, J., Nänni, I., Zachariades, C., Kemper, J. (2002) Effects of habitat fragmentation on pollinator diversity and plant reproductive success in renosterveld shrublands of South Africa. Conserv. Biol. 16(5), 1267-1276

Donzé, G., Guerin, P.M. (1994) Behavioral attributes and parental care of Varroa mites parasitizing honeybee brood. Behav. Ecol. Sociobiol. 34 (5), 305-319

du Rand, E.E., Smit, S., Beukes, M., Apostolides, Z., Pirk, C.W.W., Nicolson, S.W. (2015) Detoxification mechanisms of honey bees (Apis mellifera) resulting in tolerance of dietary nicotine. Sci. Rep. 5, 11779

Duveiller, G., Defourny, P., Desclée, B., Mayaux, P. (2008) Deforestation in Central Africa: Estimates at regional, national and landscape levels by advanced processing of systematically-distributed Landsat extracts. Remote Sens. Environ. 112, 1969-1981

Eischen, F.A., Cardoso-Tamez, D., Wilson, W.T., Dietz, A. (1989) Honey production of honey bee colonies infested with Acarapis woodi (Rennie). Apidologie 20, 1-8

El Shafie, H.A.F., Mogga, J.B.B., Basedow, T. (2002) Studies on the possible competition for pollen between the honey bee, Apis mellifera sudanensis, and the imported dwarf honey bee Apis florea (Hym., Apidae) in North-Khartoum (Sudan). J. Appl. Entomol. $126(10), 557-562$

Ellis, J.D., Munn, P.A. (2005) The worldwide health status of honey bees. Bee World 86(4), 88-101

Ellis, J.D., Graham, J.R., Mortensen, A. (2013) Standard methods for wax moth research, in: Dietemann, V., Ellis, J.D. and Neumann, P. (Eds.), The COLOSS BEEBOOK, Volume II: standard methods for Apis mellifera pest and pathogen research. J. Apic. Res. 52 (1). doi:10.3896/IBRA.1.52.1.10

El-Niweiri M.A.A. (2004) Survey of the pests and diseases of honeybees in Sudan. MSc-thesis, University of Khartoum, Khartoum, Sudan

El-Niweiri, M.A.A., El-Sarrag, M.S., Neumann, P. (2008) Filling the Sudan gap: the northernmost natural distribution limit of small hive beetles. J. Apic. Res. 47, 183-184

Elzen, P.J., Baxter, J.R., Westervelt, D., Randall, C., Delaplane, K.S., Cutts, L., Wilson, W.T. (1999) Field control and biology of a new pest species, Aethina tumida Murray (Coleoptera, Nitidulidae), attacking European honey bees in the Western hemisphere. Apidologie 30, 361-366

Engel, M.S. (1999) The taxonomy of recent and fossil honey bees (Hymenoptera: Apidae; Apis). J. Hymenopt. Res. 8, 165-196

Eyer, M., Chen, Y.-P., Schäfer, M.O., Pettis, J., Neumann, P. (2009) Small hive beetle, Aethina tumida, as a potential biological vector of honeybee viruses. Apidologie 40 (4), 419-428

Fletcher, D.J.C. (1978) The African bee, Apis mellifera adansonii, in Africa. Annu. Rev. Entomol. 23, 151171

Fombong, A.T., Mumoki, F.N., Muli, E., Masiga, D.K., Arbogast, R.T., Teal, P.E.A., Torto, B. (2013) Occurrence, diversity and pattern of damage of Oplostomus species (Coleoptera: Scarabaeidae), honey bee pests in Kenya. Apidologie 44, 11-20

Forsgren, E. (2010) European foulbrood in honey bees. J. Invertebr. Pathol. 103, S5-S9

Forsgren, E., Budge, G.E., Charrière, J-D., Hornitzky, M.A.Z. (2013) Standard methods for European 
foulbrood research, in: Dietemann, V., Ellis, J.D. and Neumann, P. (Eds.), The COLOSS BEEBOOK, Volume II: Standard methods for Apis mellifera pest and pathogen research. J. Apic. Res. 52 (1). doi:10.3896/ IBRA.1.52.1.12

Franck, P., Garnery, L., Loiseau, A., Oldroyd, B.P., Hepburn, H.R., Solignac, M., Cornuet, J.-M. (2001) Genetic diversity of the honeybee in Africa: microsatellite and mitochondrial data. Heredity 86, 420-430

Frazier, M., Muli, E., Conklin, T., Schmehl, D., Torto, B., Frazier, J., Tumlinson, J., Evans, J.D., Raina, S. (2010) A scientific note on Varroa destructor found in East Africa; threat or opportunity? Apidologie 41, 463-465

Fries, I. (2010) Nosema ceranae in European honey bees (Apis mellifera ). J. Invertebr. Pathol. 103, S73-S79

Fries, I., Raina, S. (2003) American foulbrood and African honey bees (Hymenoptera: Apidae). J. Econ. Entomol. 96, 1641-1646

Fries, I., Chauzat, M-P., Chen, Y-P., Doublet, V., Genersch, E. et al. (2013) Standard methods for Nosema research, in: Dietemann, V., Ellis, J.D. and Neumann, P. (Eds.), The COLOSS BEEBOOK, Volume II: Standard methods for Apis mellifera pest and pathogen research. J. Apic. Res. 52 (1). doi:10.3896/ IBRA.1.52.1.14

Fuchs, S. (1990) Preference for drone brood cells by Varroa jacobsoni Oud in colonies of Apis mellifera carnica . Apidologie 21, 193-199

Goulson, D., Nicholls, E., Botias, C., Rotheray, E.L. (2015) Bee declines driven by combined stress from parasites, pesticides, and lack of flowers. Science 347, 1255957

Haddad, N.J., Noureddine, A., Al-Shagour, B., LoucifAyad, W., El-Niweiri, M.A.A., Anaswah, E., Hammour, W.A., El-Obeid, D., Imad, A., Shebl, M.A., Almaleky, A.S., Nasher, A., Walid, N., Bergigui, M.F., Yañez, O., de Miranda, J.R. (2015) Distribution and variability of deformed wing virus of honeybees (Apis mellifera) in the Middle East and North Africa. Insect Science, doi:10.1111/1744-7917.12277

Hartmann, U., Forsgren, E., Charrière, J.-D., Neumann, P., Gauthier, L. (2015) Dynamics of Apis mellifera filamentous virus (AmFV) infections in honey bees and relationships with other parasites. Viruses 7, 2654 2667

Hassan, A.R., Neumann, P. (2008) A survey of the small hive beetle in Egypt. J. Apic. Res. 47, 185-186

Heath, L.A.F. (1985) Occurrence and distribution of chalk brood disease of honeybees. Bee World 66, 9-15

Hepburn, H.R. (1978) The bee louse. S. Afr. Bee J. 50 (6), 11-13

Hepburn, H.R., Allsopp, M.H. (1994) Reproductive conflict between honeybees: usurpation of Apis mellifera scutellata colonies by Apis mellifera capensis. S. Afr. J. Sci. 90 , 247-249

Hepburn, H.R., Radloff, S.E. (1998) Honeybees of Africa. Springer, Berlin

Higes, M., Martin-Hernandez, R., Garrido-Bailon, E., Botias, C., Meana, A. (2009) The presence of Nosema ceranae (Microsporidia) in North African honey bees (Apis mellifera intermissa). J. Apic. Res. 48(3), 217219

Hillesheim, E., Koeniger, N., Moritz, R.F.A. (1989) Colony performance in honeybees (Apis mellifera capensis Esch.) depends on the proportion of subordinate and dominant workers. Behav. Ecol. Sociobiol. 24(5), 291-296

Human, H., Pirk, C.W.W., Crewe, R.M., Dietemann, V. (2011) The honeybee disease American foulbrood - an African perspective. Afr. Entomol. 19(3), 551-557

Human, H., Archer, C.R., Du Rand, E.E., Pirk, C.W.W., Nicolson, S.W. (2014) Resistance of developing honeybee larvae during chronic exposure to dietary nicotine. J. Insect Physiol. 69, 74-79

Hussein, M.H. (2001a) Beekeeping in Africa. Apiacta 1 (2), 23-48

Hussein, M.H. (2001b) Beekeeping in Africa: II - Central, southern African countries and islands. Proc. 37th Int. Apic. Congr., Durban, South Africa

Jaffé, R., Dietemann, V., Allsopp, M.H., Costa, C., Crewe, R.M., Dall'Olio, R., de la Rúa, P., El-Niweiri, M.A.A., Fries, I., Kezic, N., Meusel, M.S., Paxton, R.J., Shaibi, T., Stolle, E., Moritz, R.F.A. (2010) Estimating the density of honeybee colonies across their natural range to fill the gap in pollinator decline censuses. Conserv. Biol. 24, 583-593

Jatema, D., Abebe, B. (2015) Survey on major honey bee pests and predators in Oromia special zone surrounding Finfine in Walmara district. Eur. J. Biol. Sci. 7 (2), $62-70$

Jensen, A.B., Aronstein, K., Flores, J.M., Vojvodic, S., Palacio, M.A., Spivak, M. (2013) Standard methods for fungal brood disease research, in: Dietemann, V., Ellis, J.D. and Neumann, P. (Eds.), The COLOSS BEEBOOK, Volume II: Standard methods for Apis mellifera pest and pathogen research. J. Apic. Res. 52 (1). doi:10.3896/IBRA.1.52.1.13

Johannsmeier, M.F. (1994) Overcoming the Capensis problem. S. Afr. Bee J. $69(4), 63-72$

Johannsmeier, M.F. (2001) Beekeeping history. In: Johannsmeier, M.F. (ed.) Beekeeping in South Africa, pp. 1-8. ARC-Plant Protection Research Institute, Pretoria

Johannsmeier, M.F., Mostert, A.J.N. (2001) South African nectar and pollen flora. In: Johannsmeier, M.F. (ed.) Beekeeping in South Africa, pp. 127-148. ARC-Plant Protection Research Institute, Pretoria

Judson, M.L.I. (1990) Redescription of the bee-associate Ellingsenius fulleri (Hewitt and Godfrey) (Arachnida, Chelonethi, Cheliferidae) with new records from Africa, Europe and the Middle East. J. Nat. Hist. 24, 13031310

Kajobe, R., Marris, G., Budge, G., Laurenson, L., Cordoni, G., Jones, B., Wilkins, S., Cuthbertson, A.G.S., Brown, M.A. (2010) First molecular detection of a 
viral pathogen in Ugandan honey bees. J. Invertebr. Pathol. 104, 153-156

Kasina, J.M., Mburu, J., Kraemer, M., Holm-Mueller, K. (2009) Economic benefit of crop pollination by bees: a case of Kakamega small-holder farming in western Kenya. J. Econ. Entomol. 102 (2), 467-473

Kitching, I.J. (2003) Phylogeny of the death's head hawkmoths, Acherontia [Laspeyres], and related genera (Lepidoptera: Sphingidae: Sphinginae: Acherontiini). Syst. Entomol. 28, 71-88

Klein, A.-M., Vaissiere, B.E., Cane, J.H., SteffanDewenter, I., Cunningham, S.A., Kremen, C., Tscharntke, T. (2007) Importance of pollinators in changing landscapes for world crops. Proc. R. Soc. Biol. Sci. Ser. B 274, 303-313

Knutson, L.V., Murphy, W.L. (1990) Insects: Diptera (Flies). In: Morse, R.A., Nowogrodzki, R. (eds.) Honey bee pests, predators, and diseases, pp. 121-134. Cornell University Press, London

Köhler, A., Pirk, C.W.W., Nicolson, S.W. (2012) Simultaneous stressors: Interactive effects of an immune challenge and dietary toxin can be detrimental to honeybees. J. Insect Physiol. 58(7), 918-923

Kralj, J., Fuchs, S. (2006) Parasitic Varroa destructor mites influence flight duration and homing ability of infested Apis mellifera foragers. Apidologie 37, 577-587

Kriel, G. (2015) United front needed against American foulbrood. Farmer's Weekly Magazine. pp. 16

Kryger, P., Dietemann, V., Crewe, R.M. (2003) Have we found a solution to the capensis problem? S. Afr. Bee J. 75, 123-128

Kulincevic, J.M., Rinderer, T.E., Mladjan, V.J. (1991) Effects of fluvalinate and amitraz on bee lice (Braula coeca Nitzsch) in honey-bee (Apis mellifera L.) colonies in Yugoslavia. Apidologie 22 (1), 43-47

Kumar, N.R., Kumar, R., Mbaya, J., Mwangi, R.W. (1993) Tropilaelaps clareae found on Apis mellifera in Africa. Bee World 74, 101-102

Lawal, O.A., Banjo, A.D. (2007) A checklist of pests and visitors of Apis mellifera adansonii (Honeybee) in the six states of South western Nigeria. Apiacta 42, 39-63

Lindström, A., Korpela, S., Fries, I. (2008) The distribution of Paenibacillus larvae spores in adult bees and honey and larval mortality, following the addition of American foulbrood diseased brood or spore-contaminated honey in honey bee (Apis mellifera) colonies. J. Invertebr. Pathol. 99, 82-86

Lord, W.G., Nagi, S.K. (1987) Apis florea discovered in Africa. Bee World 68, 39-40

Loucif-Ayad, W., Chefrour, A., Algharibeh, M., Haddad, N. (2013) First detection of Deformed wing virus of honeybees in Algeria. Phytoparasitica 41 (4), 445-447

Lundie, A.E. (1940) The small hive beetle Aethina tumida . Sci. Bull. Union S. Afr. 220, 5-19

Marcangeli, J., Eguaras, M., Oppedisano, M., Fernandez, N. (1993) The association between Varroa jacobsoni (Acari: Varroidae) and Braula schmitzi (Diptera:
Braulidae) in the Apis mellifera (Hymenoptera: Apidae) colonies. Apiacta 28, 65-68

Martin, S.J., Wossler, T.C., Kryger, P. (2002) Usurpation of African Apis mellifera scutellata colonies by parasitic Apis mellifera capensis workers. Apidologie 33, 215232

Martín-Hernández, R., Botías, C., Barrios, L., MartínezSalvador, A., Meana, A., Mayack, C., Higes, M. (2011) Comparison of the energetic stress associated with experimental Nosema ceranae and Nosema apis infection of honeybees (Apis mellifera). Parasitol. Res. 109 (3), 605-612

Masciocchi, M., Farji-Brener, A.G., Sackmann, P. (2010) Competition for food between the exotic wasp Vespula germanica and the native ant assemblage of NW Patagonia: evidence of biotic resistance? Biol. Invasions 12, 625-631

Matheson, A. (1993) World bee health. Bee World 74, 176-212

Matheson, A. (1995) World bee health update. Bee World 76, 31-39

McMenamin, A.J., Genersch, E. (2015) Honey bee colony losses and associated viruses. Curr. Opin. Insect Sci. 8, 121-129

Meixner, M.D., Leta, M.A., Koeniger, N., Fuchs, S. (2011) The honey bees of Ethiopia represent a new subspecies of Apis mellifera-Apis mellifera simensis n. ssp. Apidologie 42, 425-437

Meixner, M.D., Pinto, M.A., Bouga, M., Kryger, P., Ivanova, E., Fuchs, S. (2013) Standard methods for characterising subspecies and ecotypes of Apis mellifera, in: Dietemann, V., Ellis, J.D. and Neumann, P. (Eds.), The COLOSS BEEBOOK, Volume I: standard methods for Apis mellifera research. J. Apic. Res. 52 (4). doi:10.3896/IBRA.1.52.4.05

Milbrath, M.O., van Tran, T., Huang, W.F., Solter, L.F., Tarpy, D.R., Lawrence, F., Huang, Z.Y. (2015) Comparative virulence and competition between Nosema apis and Nosema ceranae in honey bees (Apis mellifera ). J. Invertebr. Pathol. 125, 9-15

Mogga, G.B., Ruttner, F. (1988) Apis florea in Africa; source of the founder population. Bee World 69, 100-103

Moritz, R.F.A. (2002) Population dynamics of the Cape bee phenomenon: The impact of parasitic laying worker clones in apiaries and natural populations. Apidologie 33, 233-244

Moritz, R.F.A., Kirchner, W.H., Crewe, R.M. (1991) Chemical camouflage of the death's head hawkmoth (Acherontia atropos L.) in honeybee colonies. Naturwissenschaften 78, 179-182

Moritz, R.F.A., de Miranda, J.R., Fries, I., Le Conte, Y., Neumann, P., Paxton, R.J. (2010a) Research strategies to improve honeybee health in Europe. Apidologie 41 (3), 227-242

Moritz, R.F.A., Haddad, N., Bataieneh, A., Shalmon, B., Hefetz, A. (2010b) Invasion of the dwarf honeybee Apis florea into the near East. Biol. Invasions 12(5), 1093-1099 
Muli, E., Patch, H., Frazier, M., Frazier, J., Torto, B., et al. (2014) Evaluation of the distribution and impacts of parasites, pathogens, and pesticides on honey bee (Apis mellifera ) populations in East Africa. PLoS One 9(4), e94459

Mumbi, C.T., Mwakatobe, A.R., Mpinga, I.H., Richard, A., Machumu, R. (2014) Parasitic mite, Varroa species (Parasitiformes: Varroidae) infesting the colonies of African honeybees, Apis mellifera scutellata (Hymenoptera: Apididae) in Tanzania. J. Entomol. Zool. Stud. 2, 188-196

Mumoki, F.N., Fombong, A., Muli, E., Muigai, W.T., Masiga, D. (2014) An inventory of documented diseases of African honeybees. Afr. Entomol. 22 (3), 473 487

Munyuli, T. (2011) Pollinator biodiversity in Uganda and in Sub-Sahara Africa: landscape and habitat management strategies for its conservation. Int. J. Biodivers. Conserv. 3 (11), 551-609

Murray, T.E., Kuhlmann, M., Potts, S.G. (2009) Conservation ecology of bees: populations, species and communities. Apidologie 40, 211-236

Mutinelli, F. (2011) The spread of pathogens through trade in honey bees and their products (including queen bees and semen): overview and recent developments. Rev. Sci. Tech. Off. Int. Epiz. 30, 257-271

Mutinelli, F., Montarsi, F., Federico, G., Granato, A., Ponti, A.M., et al. (2014) Detection of Aethina tumida Murray (Coleoptera: Nitidulidae.) in Italy: outbreaks and early reaction measures. J. Apic. Res. 53 (5), 569-575

Natsopoulou, M.E., Doublet, V., Paxton, R.J. (2015) European isolates of the Microsporidia Nosema apis and Nosema ceranae have similar virulence in laboratory tests on European worker honey bees. Apidologie . doi:10.1007/s13592-015-0375-9

Neumann, P., Carreck, N.L. (2010) Honey bee colony losses. J. Apic. Res. 49(1), 1-6

Neumann, P., Elzen, P.J. (2004) The biology of the small hive beetle (Aethina tumida, Coleoptera: Nitidulidae): Gaps in our knowledge of an invasive species. Apidologie 35 (3), 229-247

Neumann, P., Hepburn, H.R. (2002) Behavioural basis for social parasitism of Cape honeybees (Apis mellifera capensis ). Apidologie 33, 165-192

Neumann, P., Moritz, R.F.A. (2002) The Cape honeybee phenomenon: the sympatric evolution of a social parasite in real time? Behav. Ecol. Sociobiol. 52 , 271-281

Neumann, P., Radloff, S.E., Moritz, R.F.A., Hepburn, H.R., Reece, S.L. (2001) Social parasitism by honeybee workers (Apis mellifera capensis Eschscholtz): host finding and resistance of hybrid host colonies. Behav. Ecol. 12 (4), 419-428

Norris, K., Asase, A., Collen, B., Gockowksi, J., Mason, J., Phalan, B., Wade, A. (2010) Biodiversity in a forestagriculture mosaic - The changing face of West African rainforests. Biol. Conserv. 143, 2341-2350

O'Neill, K.M. (2008) Apoid wasps (Hymenoptera: Apoidea: Spheciformes). In: Capinera, J.L. (ed.)
Encyclopedia of Entomology, pp. 230-239. Springer, Netherlands

Oldroyd, B.P. (2002) The Cape honeybee: an example of a social cancer. Trends Ecol. Evol. 17, 249-251

Ollerton, J., Price, V., Armbruster, W.S., Memmott, J., Watts, S., et al. (2012) Overplaying the role of honey bees as pollinators: a comment on Aebi and Neumann (2011). Trends Ecol. Evol. 27 (3), 141-142

Ongus, J.R. (2006) Varroa destructor virus 1: A new picorna-like virus in Varroa mites as well as honey bees. PhD thesis, Wageningen University, The Netherlands

Onions, G.W. (1912) South African 'fertile worker bees'. Ag. J. Union S. Afr. 1, 720-728

Otis, G.W., Scott-Dupree, C.D. (1992) Effects of Acarapis woodi on overwintered colonies of honey bees (Hymenoptera: Apidae) in New York. J. Econ. Entomol. 85, $40-46$

Oyerinde, A.A., Ande, A.T. (2009) Distribution and impact of honey bee pests on colony development in Kwara State, Nigeria. J. Agric. Soc. Sci. 5, 85-88

Paraïso, A., Cornelissen, B., Viniwanou, N. (2011) Varroa destructor infestation of honey bee (Apis mellifera adansonii ) colonies in Benin. J. Apic. Res. 50, 321322

Paxton, R.J., Klee, J., Korpela, S., Fries, I. (2007) Nosema ceranae has infected Apis mellifera in Europe since at least 1998 and may be more virulent than Nosema apis . Apidologie 38(6), 558-565

Pettis, J.S., vanEngelsdorp, D., Johnson, J., Dively, G. (2012) Pesticide exposure in honey bees results in increased levels of the gut pathogen Nosema. Naturwissenschaften 99, 153-158

Picker, M., Griffiths, C., Weaving, A. (2004) Field guide to insects of South Africa. Struik Publishers, Cape Town

Pirk, C.W.W., Boodhoo, C., Human, H., Nicolson, S.W. (2010) The importance of protein type and protein to carbohydrate ratio for survival and ovarian activation of caged honeybees (Apis mellifera scutellata). Apidologie 41 (1), 62-72

Pirk, C.W.W., Lattorff, H.M.G., Moritz, R.F.A., Sole, C.L., Radloff, S.E., Neumann, P., Hepburn, H.R., Crewe, R.M. (2012) Reproductive biology of the Cape honeybee: a critique of Beekman et al. J. Hered. 103, 612614

Pirk, C.W.W., Human, H., Crewe, R.M., vanEngelsdorp, D. (2014) A survey of managed honey bee colony losses in the Republic of South Africa-2009 to 2011. J. Apic. Res. 53 (1), 35-42

Potts, S.G., Biesmeijer, J.C., Kremen, C., Neumann, P., Schweiger, O., Kunin, W.E. (2010) Global pollinator declines: trends, impacts and drivers. Trends Ecol. Evol. 25 (6), 345-353

Radloff, S.E., Hepburn, H.R., Engel, M.S. (2011) The Asian species of Apis . In: Hepburn, H.R., Radloff, S.E. (eds.) Honeybees of Asia, pp. 1-22. Springer, Berlin

Retschnig, G., Williams, G.R., Odemer, R., Boltin, J., Di Poto, C., Mehmann, M.M., Retschnig, P., Winiger, P., 
Rosenkranz, P., Neumann, P. (2015) Effects, but no interactions, of ubiquitous pesticide and parasite stressors on honey bee (Apis mellifera) lifespan and behaviour in a colony environment. Environ. Microbiol. . doi:10.1111/1462-2920.12825

Ribière, M., Olivier, V., Blanchard, P. (2010) Chronic bee paralysis: A disease and a virus like no other? J. Invertebr. Pathol. 103, S120-S131

Rosenkranz, P., Aumeier, P., Ziegelmann, B. (2010) Biology and control of Varroa destructor. J. Invertebr. Pathol. 103, S96-S119

Runckel, C., Flenniken, M.L., Engel, J.C., Ruby, J.G., Ganem, D., Andino, R., DeRisi, J.L. (2011) Temporal analysis of the honey bee microbiome reveals four novel viruses and seasonal prevalence of known viruses, Nosema, and Crithidia. PLoS One 6, e20656

Ruttner, F. (1988) Biogeography and Taxonomy of Honeybees. Springer, Berlin

Ruttner, F. (1992) Naturgeschichte der Honigbienen. Ehrenwirth, München

Sammataro, D., Avitabile, A. (2011) The Beekeeper's Handbook. Cornell University Press, Ithaca

Sammataro, D., de Guzman, L., George, S., Ochoa, R., Otis, G. (2013) Standard methods for tracheal mites research, in: Dietemann, V., Ellis, J.D. and Neumann, P. (Eds.), The COLOSS BEEBOOK, Volume II: Standard methods for Apis mellifera pest and pathogen research. J. Apic. Res. 52 (4). doi:10.3896/ IBRA.1.52.4.20

Sanad, R.E., Mohanny, K.M. (2011) Survey and management of the chalk brood fungal disease infecting honeybee colonies by natural agents at Qena Governorate, Upper Egypt. Egypt. J. Biol. Pest. Co. $21,251-256$

Schäfer, M.O., Ritter, W., Pettis, J.S., Neumann, P. (2010) Small hive beetles, Aethina tumida, are vectors of Paenibacillus larvae. Apidologie 41 , 14-20

Schneider, P., Drescher, W. (1987) Einfluss der Parasitierung durch die Milbe Varroa jacobsoni Oud auf das schlupfgewicht, die gewichtsentwicklung, die entwicklung der hypopharynxdrüsen und die lebensdauer von Apis mellifera L. Apidologie 18, 101-110

Schneider, S.S., DeGrandi-Hoffman, G., Smith, D.R. (2004) The African honeybee: Factors contributing to a successful biological invasion. Annu. Rev. Entomol. 49, 351-376

Skaife, S.H. (1920) A tachinid parasite of the honey bee. S. Afr. J. Sci. 17, 196-200

Smith, K.M., Loh, E.H., Rostal, M.K., ZambranaTorrelio, C.M., Mendiola, L., Daszak, P. (2013) Pathogens, pests, and economics: Drivers of honey bee colony declines and losses. EcoHealth 10, 434-445

Strauss, U., Human, H., Gauthier, L., Crewe, R.M., Dietemann, V., Pirk, C.W.W. (2013) Seasonal prevalence of pathogens and parasites in the savannah honeybee (Apis mellifera scutellata). J. Invertebr. Pathol. 114 (1), 45-52

Strauss, U., Pirk, C.W.W., Dietemann, V., Crewe, R.M., Human, H. (2014) Infestation rates of Varroa destructor and Braula coeca in the savannah honey bee (Apis mellifera scutellata). J. Apic. Res. 53, 475477

Swart, D.J., Johannsmeier, M.F., Tribe, G.D., Kryger, P. (2001) Diseases and pests of honeybees. In: Johannsmeier, M.F. (ed.) Beekeeping in South Africa, pp. 198-222. ARC-Plant Protection Research Institute, Pretoria

Thapa, R., Wongsiri, S., Lee, M.L., Choi, Y.-S. (2013) Predatory behaviour of pseudoscorpions (Ellingsenius indicus) associated with Himalayan Apis cerana. J. Apic. Res. 52, 219-226

Tribe, G.D., Richardson, D.M. (1994) The European wasp, Vespula germanica (Fabricius) (Hymenoptera: Vespidae), in southern Africa and its potential distribution as predicted by ecoclimatic matching. Afr. Entomol. 2, 1-6

Vanbergen, A.J., Baude, M., Biesmeijer, J.C., Britton, N.F., Brown, M.J.F., et al. (2013) Threats to an ecosystem service: pressures on pollinators. Front. Ecol. Environ. 11, 251-259

vanEngelsdorp, D., Meixner, M.D. (2010) A historical review of managed honey bee populations in Europe and the United States and the factors that may affect them. J. Invertebr. Pathol. 103, S80-S95

Vidau, C., Diogon, M., Aufauvre, J., Fontbonne, R., Viguès, B., et al. (2011) Exposure to sublethal doses of fipronil and thiacloprid highly increases mortality of honeybees previously infected by Nosema ceranae. PLoS One 6 (6), e 21550

WAHID Interface (2015) World Animal Health Information Database (WAHID) Interface [online] http:// www.oie.int/wahis_2/public/wahid.php/Wahidhome/ Home (accessed on 31 August 15)

Wallberg, A., Han, F., Wellhagen, G., Dahle, B., Kawata, M., et al. (2014) A worldwide survey of genome sequence variation provides insight into the evolutionary history of the honeybee Apis mellifera. Nat. Genet. 46, 1081-1088

Williams, G.R., Shutler, D., Burgher-MacLellan, K.L., Rogers, R.E.L. (2014) Infra-population and community dynamics of the parasites Nosema apis and Nosema ceranae, and consequences for honey bee (Apis mellifera) hosts. PLoS One 9, e99465

Williamson, S.M., Wright, G.A. (2013) Exposure to multiple cholinergic pesticides impairs olfactory learning and memory in honeybees. J. Exp. Biol. 216(10), 1799-1807

Yang, E., Chuang, Y., Chen, Y., Chang, L. (2008) Abnormal foraging behavior induced by sublethal dosage of imidacloprid in the honey bee (Hymenoptera: Apidae). J. Econ. Entomol. 101 (6), 1743-1748

Yohannes, A., Bezabeh, A., Yaekob, B., Begna, D., Shiferaw, Y., Kebede, Y., Kebede, N. (2009) Ecological distribution of honeybee chalkbrood disease 
(Ascosphaera apis) in Ethiopia. Ethiop. J. Anim. Prod. 9, 177-191

Zagorinsky, A.A., Zhantiev, R.D., Korsunovskaya, O.S. (2012) The sound signals of hawkmoths (Lepidoptera, Sphingidae). Entomol. Rev. 92, 601-604

Zaitoun, S., Al-Ghzawi, A.A.M. (2008) Daily number of bee louse (Braula coeca) in honey bee (Apis mellifera carnica and $A$. $m$. syriaca) colonies maintained under semi-arid conditions. Insect Sci. $15(6), 563-567$
Zheng, H.-Q., Dietemann, V., Crewe, R.M., Hepburn, H.R., Hu, F.-L., Yang, M.X., Pirk, C.W.W. (2010) Pheromonal predisposition to social parasitism in the honeybee Apis mellifera capensis. Behav. Ecol. 21, 12211226

Zioni, N., Soroker, V., Chejanovsky, N. (2011) Replication of Varroa destructor virus 1 (VDV-1) and a Varroa destructor virus 1 - deformed wing virus recombinant (VDV-1-DWV) in the head of the honey bee. Virology 417, 106-112 